\title{
Heat capacity and phase equilibria of almandine, $\mathrm{Fe}_{3} \mathrm{Al}_{2} \mathrm{Si}_{3} \mathrm{O}_{12}$
}

\author{
L. M. Anovit7,, ${ }^{1}$ E. J. Essene, ${ }^{2}$ G. W. MEtz, ${ }^{2 *}$ S. R. Bohi.en, ${ }^{3}$ E. F. Westrum JR., ${ }^{4}$ and B. S. HemingWay ${ }^{3}$ \\ 'Department of Geosciences, University of Arizona, Tucson AZ 85721, USA \\ ${ }^{2}$ Department of Geological Sciences, University of Michigan, Ann Arbor, MI 48109-1063, USA \\ ${ }^{3}$ US Geological Survey, 345 Middlefield Rd., Menlo Park CA 94025, USA \\ 4 Department of Chemistry, University of Michigan, Ann Arbor, MI 48109-1055, USA \\ ${ }^{5}$ US Geological Survey, 959 National Center, Reston, VA 22097, USA
}

(Received December 27, 1991; accepted in revised form February 2, 1993)

\begin{abstract}
The heat capacity of a synthetic almandine, $\mathrm{Fe}_{3} \mathrm{Al}_{2} \mathrm{Si}_{3} \mathrm{O}_{12}$, was measured from 6 to $350 \mathrm{~K}$ using equilibrium, intermittent-heating quasi-adiabatic calorimetry and from 420 to $1000 \mathrm{~K}$ using differential scanning calorimetry. These measurements yield $\mathrm{Cp}_{298}=342.80 \pm 1.4 \mathrm{~J} / \mathrm{mol} \cdot \mathrm{K}$ and $S_{298}^{\circ}$ $=342.60 \mathrm{~J} / \mathrm{mol} \cdot \mathrm{K}$. Mössbauer characterizations show the almandine to contain less than $2 \pm 1 \%$ of the total iron as $\mathrm{Fe}^{3+} . \mathrm{X}$-ray diffraction studies of this synthetic almandine yield $a=11.521 \pm 0.001 \AA$ and $V_{298}^{o}=115.11 \pm 0.01 \mathrm{~cm}^{3} / \mathrm{mol}$, somewhat smaller than previously reported. The low-temperature $\mathrm{Cp}$ data indicate a lambda transition at $8.7 \mathrm{~K}$ related to an antiferromagnetic-paramagnetic transition with $T_{\mathrm{N}}=7.5 \mathrm{~K}$. Modeling of the lattice contribution to the total entropy suggests the presence of entropy in excess of that attributable to the effects of lattice vibrations and the magnetic transition. This probably arises from a low-temperature electronic transition (Schottky contribution).

Combination of the $\mathrm{Cp}$ data with existing thermodynamic and phase equilibrium data on almandine yields $\Delta G_{\mathrm{f}, 298}^{\circ}=-4938.3 \mathrm{~kJ} / \mathrm{mol}$ and $\Delta H_{\mathrm{f}, 298}^{\circ}=-5261.3 \mathrm{~kJ} / \mathrm{mol}$ for almandine when calculated from the elements. The equilibrium almandine $=$ hercynite + fayalite + quartz limits the upper $T / P$ for alnıandine and is metastably located at ca. $570^{\circ} \mathrm{C}$ at $P=1$ bar, with a $d P / d T$ of +17 bars $/{ }^{\circ} \mathrm{C}$. This agrees well with reversed experiments on almandine stability when they are corrected for magnetite and hercynite solid-solutions. In $f_{\mathrm{O}_{2}}-T$ space, almandine oxidizes near QFM by the reactions almandine $+\mathrm{O}_{2}$ $=$ magnetite + sillimanite + quartz and almandine $+\mathrm{O}_{2}=$ hercynite + magnetite + quartz. With suitable correction for reduced activities of solid phases, these equilibria provide useful oxygen barometers for medium- to high-grade metamorphic rocks.
\end{abstract}

\section{INTRODUCTION}

AlMANDINE, $\mathrm{Fe}_{3} \mathrm{Al}_{2} \mathrm{Si}_{3} \mathrm{O}_{12}$, is an important component in many natural garnets. The first appearance of almandinerich garnet in metapelitic rocks has been used as an indicator of metamorphic grade since the work of BARROW (1893). Almandine-rich garnets appear in metamorphic rocks of varied composition from the upper greenschist to the granulite facies and they are also found in some granites and pegmatites. The wide stability field of almandine-rich garnets enables equilibria involving almandine to be used as sensors of temperature $(T)$, pressure $(P)$, and oxygen fugacity $\left(f_{\mathrm{O}_{2}}\right)$ in many crustal rocks.

Accurate calculation of equilibria involving almandine requires knowledge of its thermodynamic properties. Until recently, accurate low-temperature heat capacity data on ironbearing minerals have been unavailable as a result of the difficulty of obtaining suitable samples. Most natural garnets are inappropriate for heat capacity measurements because of the presence of solid solutions, chemical inhomogeneities, and mineral inclusions. On the other hand, synthesis of a large (approximately $10 \mathrm{~g}$ ) sample presented severe experimental problems until one of us (S. R. Bohlen) designed a new large-volume furnace for the piston-cylinder device and developed a synthesis technique that provided high yields of coarse garnet crystallites.

* Present address: 1825 Nemoke Trail, Haslett, MI 48840, USA.
The heat capacity of synthetic almandine has been measured from 8 to $350 \mathrm{~K}$ using adiabatic calorimetry and from 420 to $1000 \mathrm{~K}$ using differential scanning calorimetry (DSC). These data, combined with volume, thermochemical, and phase equilibrium data, permit calculation of the Gibbs energy of almandine, which allows the stability of endmember almandine to be calculated in $P-T-f_{\mathrm{O}_{2}}$ space and compared with existing experiments.

\section{EXPERIMENTAL TECHNIQUES}

\section{Sample Preparation and Characterization}

The measurements were performed on a synthetic almandine prepared in the laboratory of Prof. A. L. Montana at UCLA. A vitreous phase of almandine composition was synthesized by reacting $\mathrm{Fe}_{2} \mathrm{O}_{3}$ (Baker reagent grade hematite), $\mathrm{Al}_{2} \mathrm{O}_{3}$ (synthetic corundum), and $\mathrm{SiO}_{2}$ (natural quartz from Brazil, crushed to -200 mesh, leached in $\mathrm{HNO}_{3}$, and fired at $800^{\circ} \mathrm{C}$ for $24 \mathrm{~h}$ ) in a graphite crucible with a tight-fitting lid at $1375^{\circ} \mathrm{C}$ for $45 \mathrm{~min}$. Traces of excess $\mathrm{SiO}_{2}$ were added to promote dissolution of refractory corundum. Optical examination of the product, a black-green, homogeneous glass, showed no unreacted starting material; and $X$-ray analysis showed no diffraction peaks. The glass was then ground and loaded into a graphite capsule that was placed, in turn, in a 1 in. talc assembly identical to that described by A. L. Boettcher (in JoHANNES et al., 1971). Almandine was synthesized at $950^{\circ} \mathrm{C}$ and $22 \mathrm{kbar}$ for $8 \mathrm{~h}$ in the pistoncylinder apparatus in 3 to $4 \mathrm{~g}$ batches. Optical examination of the product revealed that the glass had completely reacted to garnet with only traces $(<0.1 \%)$ of a low refractive index, crystalline phase, probably quartz. Electron microprobe analyses suggest that the garnet is homogeneous, stoichiometric almandine (Table 1). Powder X-ray diffraction analysis gives the pattern of garnet $(a-11.521 \pm 0.001$ $\AA$ ) only. This cell edge is somewhat smaller than those previously 
TABLE 1 . Analysis of synthetic almandine.*

\begin{tabular}{lcccc}
\hline Synthesis \# & \multicolumn{1}{c}{865} & 866 & 871 & \multicolumn{1}{c}{874} \\
\hline $\mathrm{SiO}_{2}$ & $36.1(0.3)$ & $36.2(0.2)$ & $36.2(0.3)$ & $36.1(0.2)$ \\
$\mathrm{Al}_{2} \mathrm{O}_{3}$ & $20.5(0.4)$ & $20.4(0.3)$ & $20.5(0.2)$ & $20.5(0.5)$ \\
$\mathrm{FeO}$ & $43.3(0.3)$ & $43.4(0.4)$ & $43.4(0.2)$ & $43.2(0.3)$ \\
Total & 99.9 & 100.0 & 100.1 & 99.8
\end{tabular}

cations normalized to twelve oxygens

\begin{tabular}{lllll}
$\mathrm{Si}$ & 2.996 & 3.001 & 3.000 & 2.998 \\
$\mathrm{Al}$ & 2.004 & 1.993 & 2.002 & 2.002 \\
$\mathrm{Fe}$ & 3.004 & 3.008 & 3.005 & 3.001 \\
$\mathrm{O}$ & 12 & 12 & 12 & 12 \\
\# points & 14 & 12 & 15 & 15 \\
\hline
\end{tabular}

* Numbers in parentheses indicate the total variation in $w t \%$ of the analyses.

reported for almandine: $11.526 \AA$ (ROBIE et al., 1967), 11.525-11.528 $\AA$ (HsU, 1968), $11.529 \AA$ (KAWASAKI and MATSUI, 1977), and $11.527 \AA$ (CHATILLON-COLINET et al., 1983). This difference may be the result of greater $\mathrm{Fe}^{3+}$ content in other synthetic almandines (WOODLAND and WOOD, 1989). The cell edge for the almandine used in this study was determined from powder X-ray data obtained in the range of 15 to $95^{\circ} 2 \theta$ at a constant scan rate of $0.5^{\circ} 2 \theta / \mathrm{min}$ using quartz as an internal standard. The cell edge was determined by least-squares regression using fifteen $\mathrm{X}$-ray lines of the powder data. This yields $V_{298}^{\circ}=115.11 \pm 0.01 \mathrm{~cm}^{3} / \mathrm{mol}$ for the synthetic almandine.

\section{Mos̈sbauer Studies}

Mosisbauer spectra of the almandine were obtained at $300 \mathrm{~K}$ using a constant acceleration, mechanically driven Mössbauer spectrometer in the laboratory of Prof. W. A. Dollase at UCLA to check for the presence of $\mathrm{Fe}^{3+}$. Samples of $70-80 \mathrm{mg}$ were used with a $10 \mathrm{mCi}$ ${ }^{57} \mathrm{Co}$ in Pd source. Duplicate spectra were recorded in 512 channels of a multichannel analyzer using a velocity increment of $0.03 \mathrm{~mm} /$ channel sec. Counting times were sufficient to obtain several million counts per channel and count dips of greater than $10^{5}$ counts. The spectra were fit with Lorentzian doublets that were constrained to equal widths and area for the low- and high-velocity components. Chi-square and additional goodness-of-fit parameters (RUBY, 1973) were calculated for each spectrum fitted.

The Mössbauer spectrum of this almandine consists of a ferrous doublet that is very widely split in comparison with that of other ferrous iron silicates and a very small, poorly defined ferric doublet that appears in the spectrum as a low-intensity "shoulder" on the high-velocity edge of a low-velocity component of the ferrous doublet. For ferrous iron in the dodecahedral position, the measured average isomer shift and quadrupole splitting ( IS $_{\mathrm{Fe}}=1.299 \pm 0.002 \mathrm{~mm}$ / $\mathrm{sec}, \mathrm{Qs}=3.546 \pm 0.004 \mathrm{~mm} / \mathrm{sec}$ ) are close to reported values for both natural garnet (AMTHAUER et al., 1976) and for synthetic, endmember almandine (MURAD and WAGNER, 1987; AMTHAUER et al., 1989; GEIGER et al., 1990). The observed peak widths are 0.3 $\mathrm{mm} / \mathrm{sec}$. The intensity of the ferric doublet is so low that in order to obtain convergence during the fitting procedure, the isomer shift and quadrupole splitting had to be constrained. The values chosen were consistent with ferric iron in octahedral sites in one case and tetrahedral sites in another. Both solutions fit the data equally well. However, by constraining the values of IS and Qs, only the relative proportion of ferrous and ferric iron could be obtained from the data. The areas of the ferrous and ferric doublets indicate that $2 \pm 1 \%$ of the iron is present in the ferric state.

\section{Calorimetric Methods}

Low-temperature measurements were performed on a $10.8618 \mathrm{~g}$ mass of the synthetic almandine. The sample was loaded in calorimeter W-34 and evacuated. Before sealing, ca. 20 torr of purified He was added to promote thermal conductivity. Amounts of $\mathrm{He}$, solder, and conductive grease used were comparable to those used in measuring the heat capacity of the empty calorimeter, and corrections were applied for the differences. The experiment was performed in the Mark X cryostat using the automated data collection techniques described in WESTRUM (1984) using temperature increments of $5 \%$ of $T$ for temperatures below $100 \mathrm{~K}$ and increments of $5 \mathrm{~K}$ at temperatures between 100 and $350 \mathrm{~K}$. All measurements of mass, energy, and temperature are traceable to National Institute of Standards and Technology calibrations. The molecular weight of $497.753 \mathrm{gm} / \mathrm{mol}$ for pure $\mathrm{Fe}_{3} \mathrm{Al}_{2} \mathrm{Si}_{3} \mathrm{O}_{12}$ was used to convert the data to moles.

The heat capacity of $44.056 \mathrm{mg}$ of the almandine was measured between 420 and $1000 \mathrm{~K}$ using the differential scanning calorimeter at the USGS. The procedures and methods of data treatment are discussed elsewhere (HEMINGWAY et al., 1981).

\section{RESULTS}

The experimental values for the low-temperature heat capacity of almandine are shown as a function of temperature in chronological order in Table 2 . The values tabulated have been corrected for curvature and for the contribution of the empty calorimeter. The uncertainty in the individual $\mathrm{Cp}$ measurements is approximately $0.1 \%$. Figure 1 is a plot of Cp vs. $T$; above $10 \mathrm{~K}$, the data fit a smooth, continuous sigmate curve. Below $10 \mathrm{~K}$, the data reveal a lambda transition with a peak at $8.7 \mathrm{~K}$ attributable to magnetic ordering of the $\mathrm{Fe}^{2+}$ electrons. Using magnetic susceptibility measurements, PRANDEL (1971) observed an antiferromagnetic ordering transition (Néel point) in synthetic almandine at $7.5 \mathrm{~K}$. The difference in temperature may be attributable to uncertainties in the temperature scale at these temperatures or to differences in the $\mathrm{Fe}^{3+}$ content of the synthetic almandines. The heat capacity of this region was remeasured using small temperature intervals to define the transition more accurately. The lack of sensitivity in the thermometer calibration at these temperatures suggests that errors in $T$ are at least $\pm 0.25 \mathrm{~K}$. Limitations of the cryostat hampered data collection on the low-temperature side of the transition, and this limb was estimated using the known relationship of $\mathrm{Cp}$ to $T$ below such a transition (KITTEL, 1986).

The enthalpy and entropy contribution from the transition were found by graphically fitting a curve to the data in the transition region and using values interpolated from this curve (Fig. 1) to numerically integrate the $\mathrm{Cp}$ and $\mathrm{Cp} / T$ functions. Above $12 \mathrm{~K}$, the data were fit in two segments $(12-55 \mathrm{~K}$ and $55-350 \mathrm{~K}$ ) with orthogonal polynomials using the program FITAB2 (JusticE, 1969). The smoothed data fit the experimental results within $0.14 \%$ at $20 \mathrm{~K}, 0.22 \%$ at $50 \mathrm{~K}, 0.1 \%$ at $100 \mathrm{~K}$, and $0.03 \%$ at $325 \mathrm{~K}$. These data were combined with those from the transition region to yield $\mathrm{Cp}_{298}=342.8$ $\mathrm{J} / \mathrm{mol} \cdot \mathrm{K}$ and $S_{298}^{\circ}=342.6 \mathrm{~J} / \mathrm{mol} \cdot \mathrm{K}$. The uncertainty in the entropy value is a combination of the uncertainties in the heat capacity data and is estimated at approximately $0.4 \%$ of the total or $1.4 \mathrm{~J} / \mathrm{mol} \cdot \mathrm{K}$. Smoothed thermodynamic functions at selected temperatures are listed in Table 3.

The results of the high-temperature measurements are in Table 4, where each series represents a continuous thermal scan. The experimental heat capacities are fit by the following equation:

$$
\begin{array}{r}
\mathrm{Cp}(\mathrm{J} / \mathrm{g} \cdot \mathrm{K})=0.58812+6.961610^{-4} T-3.077310^{-7} T^{2} \\
+1.439 T^{-0.5}-1.448510^{4} T^{-2}
\end{array}
$$


TABLE 2. Experimental heat capacities for almandine (6-350 K).

\begin{tabular}{|c|c|c|c|c|c|}
\hline $\begin{array}{l}T \\
\mathbf{K}\end{array}$ & $\underset{\mathrm{J} / \mathrm{mol} \mathrm{K}}{\mathrm{Cp}}$ & $\begin{array}{l}T \\
\mathbf{K}\end{array}$ & $\begin{array}{c}\text { Cp } \\
\mathrm{J} / \mathrm{mol} \mathrm{K}\end{array}$ & $\begin{array}{l}T \\
\mathrm{~K}\end{array}$ & $\underset{\mathrm{J} / \mathrm{mol} \mathrm{K}}{\mathrm{Cp}}$ \\
\hline \multicolumn{2}{|c|}{ SERIES I } & 38.24 & 22.975 & 264.50 & 316.034 \\
\hline 6.81 & 27.583 & 40.05 & 24.824 & 269.66 & 321.226 \\
\hline 7.15 & 27.255 & 41.94 & 26.768 & 274.81 & 324.976 \\
\hline 7.63 & 30.714 & 43.93 & 28.872 & 279.97 & 329.366 \\
\hline 8.03 & 33.514 & 46.01 & 31.571 & 285.12 & 333.177 \\
\hline 8.50 & 37.681 & 48.20 & 34.184 & 290.30 & 337.318 \\
\hline 9.00 & 36.835 & 50.50 & 36.878 & 295.47 & 339.073 \\
\hline 9.69 & 21.515 & 52.91 & 40.232 & 300.59 & 344.382 \\
\hline 10.45 & 17.065 & 55.44 & 43.527 & 305.70 & 348.479 \\
\hline 11.03 & & 57.83 & 94 & & 52.216 \\
\hline 11.55 & & 60. & & & 337 \\
\hline 12.07 & 15.658 & 63.26 & 55.023 & 21.22 & 59.814 \\
\hline 12.58 & 15.414 & 66.07 & 59.045 & 326.43 & 362.924 \\
\hline \multicolumn{2}{|c|}{ SERIES II } & 69.13 & 63.579 & 331.57 & 366.042 \\
\hline 6.92 & 21.806 & 72.78 & 69.008 & 336.70 & 370.145 \\
\hline 7.35 & 27.448 & 76.66 & 74.871 & 341.85 & 374.191 \\
\hline 7.78 & 30.803 & 80.56 & 81.284 & 347.01 & 377.120 \\
\hline 8.16 & 35.28 & 84.88 & 88.959 & \multicolumn{2}{|c|}{ SERIES IV } \\
\hline 8.50 & 37.998 & 89.80 & 95.980 & 177.10 & 224.012 \\
\hline 8.82 & 38.410 & 96.23 & 106.381 & 182.20 & 941 \\
\hline 9.11 & 35.3 & 101.00 & 13.781 & 192.43 & 42.802 \\
\hline 9.41 & 25.5 & 05.96 & 121.632 & 197.56 & \\
\hline 9.81 & 19.194 & 110.94 & 129.431 & 202.69 & 54.309 \\
\hline 10.28 & 17.487 & 115.93 & 137.241 & 207.82 & 260.040 \\
\hline 10.78 & $1,6.571$ & 120.94 & 144.785 & 212.95 & 265.337 \\
\hline \multicolumn{2}{|c|}{ SERIES III } & 125.96 & 152.740 & 218.08 & 271.107 \\
\hline 8.88 & 30.858 & 131.00 & 160.373 & 223.22 & 276.362 \\
\hline 11.56 & 16.008 & 136.04 & 168.119 & 228.36 & 281.888 \\
\hline 12.12 & 15.6 & 141.10 & 175.150 & 233.50 & 287.226 \\
\hline$! 2.75$ & 15.3 & 6.16 & & 38.65 & 234 \\
\hline 13.41 & & 1.29 & & 3.79 & 252 \\
\hline 14.09 & & 56.47 & 97.299 & $\$ 8.94$ & \\
\hline 14.81 & 15.127 & 161.65 & 204.110 & 254.09 & 307.133 \\
\hline 15.56 & 15.004 & 166.84 & 210.923 & 259.30 & 319.572 \\
\hline 16.35 & 14.881 & 172.03 & 218.235 & 264.42 & 315.855 \\
\hline 17.17 & 14.665 & 177.17 & 224.503 & 269.56 & 320.569 \\
\hline 18.03 & 14.523 & 182.29 & 231.141 & 274.72 & 324.440 \\
\hline 18.93 & 14.419 & 187.41 & 237.048 & 279.88 & 328.162 \\
\hline 19.87 & 14.340 & 192.54 & 243.184 & 285.05 & 332.686 \\
\hline 20.85 & & & & & 337.416 \\
\hline 21.87 & & & & & \\
\hline 22.94 & 14 & 207.92 & & 300.57 & \\
\hline 24.05 & 14.542 & 213.05 & 265.681 & 305.71 & 347.693 \\
\hline 25.21 & 14.772 & 218.19 & 270.948 & 310.90 & 351.57 \\
\hline 26.42 & 15.044 & 223.32 & 276.628 & 316.11 & 355.35 \\
\hline 27.68 & 15.548 & 228.46 & 281.922 & 321.28 & 358.89 \\
\hline 28.99 & 16.139 & 233.60 & 287.045 & 326.45 & 362.35 \\
\hline 30.37 & 16.790 & 238.74 & 292.678 & 331.64 & 365.71 \\
\hline 31.80 & 17.696 & 243.87 & 298.777 & 336.83 & 369.609 \\
\hline 33.30 & & 249.02 & 302.338 & 341.99 & 373.460 \\
\hline 34.87 & 19.966 & 254.19 & 307.268 & & \\
\hline 36.52 & 21.345 & 259.35 & 311.579 & & \\
\hline
\end{tabular}

with an average deviation of $0.3 \%$. A plot of $\mathrm{Cp}$ vs. $T$ shows that the two sets of measurements produce curves that overlap smoothly (Fig. 2). Smoothed values for the thermodynamic functions are given in Table 5 at selected temperatures to $1000 \mathrm{~K}$. No correction was made for the small amount of ferric iron shown by the Mössbauer spectra because of the uncertainty in the substitutional mechanism.

\section{Lattice Heat Capacity}

The most important source of heat capacity in a solid, the lattice contribution, arises from the vibrational energy of the structure. This contribution may be calculated using the principles of lattice dynamics, provided that spectral data are available. For most minerals, such data are unavailable or incomplete and other techniques must be applied to evaluate the lattice $\mathrm{Cp}$. In addition to lattice vibrations, other factors such as order-disorder and magnetic transitions, as well as thermally excited electronic transitions, may also contribute to heat capacity.

The lattice contribution for almandine was estimated from the heat capacity of isostructural grossular, $\mathrm{Ca}_{3} \mathrm{Al}_{2} \mathrm{Si}_{3} \mathrm{O}_{12}$. The heat capacity of natural grossular has been measured by WESTRUM et al. (1979) and by KOLESNIK et al. (1979) and that of synthetic grossular by HASELTON and WESTRUM (1980). Grossular is free of excess contributions, while pyrope was rejected as a lattice model because pyrope appears to have an anomalously high heat capacity at low temperatures (KIEFFER, 1980; HASELTON and WESTRUM, 1980).

The apparent Debye characteristic temperatures $\left(\theta_{D}\right)$ for the experimental data on almandine (this study) and for that of grossular (WESTRUM et al., 1979) should differ by a constant value if lattice vibrations are the only contribution to their heat capacities. Any nonparallelism would represent excess contributions. The $\theta_{\mathrm{D}}$ curve of almandine was redrawn to parallel the curve for grossular. The temperature dependence of the lattice heat capacity was ascertained from these new values (Fig. 3).

Recent data suggest that the use of grossular as a lattice model for almandine may be problematic. ARMBRUSTER et al. (1991, 1992) showed that in almandine-pyrope garnets, there is a strong anisotropic vibration of the cation in the large X-site. In grossular, there is significantly less anisotropic vibration of the larger $\mathrm{Ca}$ atom (C. A. Geiger, pers. commun.); thus, the lattice contributions to the heat capacities will be different in almandine and grossular. Such differences will be accounted for to some extent by the Debye temperature correction discussed in the preceding text. In addition, cation size is not the only factor to be considered. The heat capacities of almandine and pyrope also differ because of the

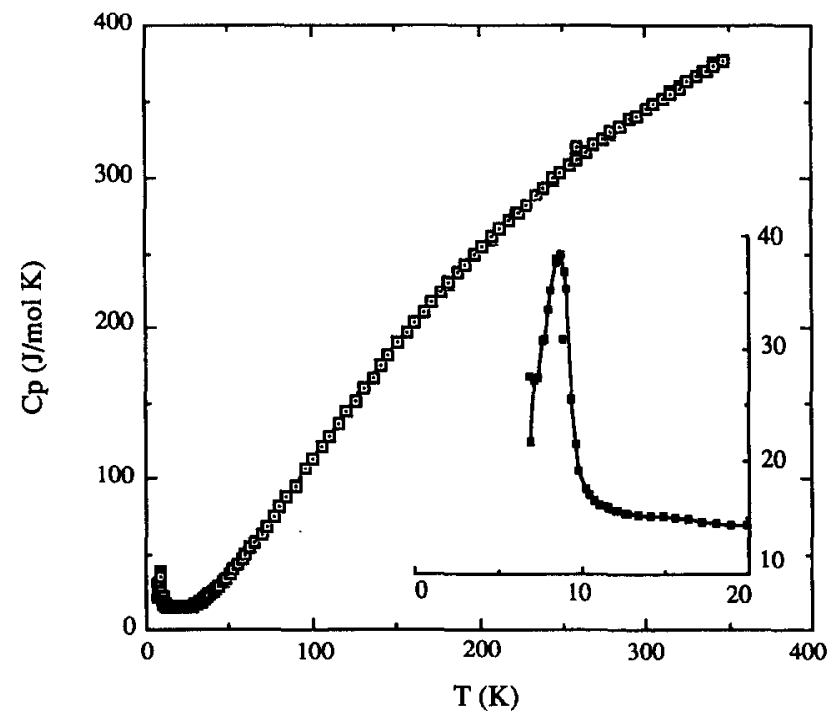

Fig. 1. Low-temperature $\mathrm{Cp}$ vs. $T$ for almandine. Note the lambda transition at $8.7 \mathrm{~K}$. Inset shows detail for the transition region. 
TABLE 3. Smoothed thermodynamic functions for almandine $(10-350 \mathrm{~K})$

\begin{tabular}{|c|c|c|c|c|}
\hline $\begin{array}{l}T \\
\mathbf{K}\end{array}$ & $\begin{array}{c}\mathrm{Cp} \\
\mathrm{J} / \mathrm{mol} \mathrm{K}\end{array}$ & $\begin{array}{l}S_{T}-S_{0} \\
\mathrm{~J} / \mathrm{mol} \mathrm{K}\end{array}$ & $\begin{array}{c}\left(H_{T}^{\circ}-H_{0}^{\circ}\right) / T \\
\mathrm{~J} / \mathrm{mol} \mathrm{K}\end{array}$ & $\begin{array}{c}\left(G_{T}^{\circ}-H_{0}^{\circ}\right) / T \\
\mathrm{~J} / \mathrm{mol} \mathrm{K}\end{array}$ \\
\hline 10 & 16.25 & 23.79 & 178.6 & 5.936 \\
\hline 15 & 15.02 & 30.13 & 256.5 & 13.028 \\
\hline 20 & 14.35 & 34.34 & 329.6 & 17.858 \\
\hline 25 & 14.71 & 37.55 & 401.7 & 21.483 \\
\hline 30 & 16.59 & 40.38 & 479.3 & 24.402 \\
\hline 35 & 20.05 & 43.17 & 570.3 & 26.879 \\
\hline 40 & 24.75 & 46.15 & 681.9 & 29.099 \\
\hline 45 & 30.28 & 49.38 & 819.2 & 31.177 \\
\hline 50 & 36.37 & 52.88 & 985.6 & 33.165 \\
\hline 60 & 50.07 & 60.70 & 1416.5 & 37.089 \\
\hline 70 & 64.94 & 69.52 & 1990.9 & 41.079 \\
\hline 80 & 80.43 & 79.20 & 2717.3 & 45.236 \\
\hline 90 & 96.22 & 89.58 & 3600.5 & 49.576 \\
\hline 100 & 112.11 & 100.54 & 4641.7 & 54.124 \\
\hline 110 & 127.95 & 111.97 & 5842.2 & 58.855 \\
\hline 120 & 143.58 & 123.78 & 7199.9 & 63.777 \\
\hline 130 & 158.88 & 135.85 & 8713.1 & 68.857 \\
\hline 140 & 173.85 & 148.24 & 10377.5 & 74.078 \\
\hline 150 & 188.23 & 160.71 & 12188.3 & 79.440 \\
\hline 160 & 202.03 & 173.26 & 14139.6 & 84.911 \\
\hline 170 & 215.25 & 185.90 & 16227.3 & 90.481 \\
\hline 180 & 227.89 & 198.62 & 18443.8 & 96.114 \\
\hline 190 & 239.94 & 211.26 & 20783.3 & 101.863 \\
\hline 200 & 251.50 & 223.81 & 23240.9 & 107.641 \\
\hline 210 & 262.56 & 236.37 & 258111.6 & 113.478 \\
\hline 220 & 273.20 & 248.84 & 28491.2 & 119.347 \\
\hline 230 & 283.59 & 261.23 & 31275.6 & 125.209 \\
\hline 240 & 293.48 & 273.53 & 34160.6 & 131.195 \\
\hline 250 & 303.13 & 285.67 & 37144.4 & 137.098 \\
\hline 260 & 312.27 & 297.72 & 40221.5 & 143.084 \\
\hline 270 & 320.92 & 309.70 & 43390.8 & 448.987 \\
\hline 273.15 & 323.58 & 313.44 & 44405.1 & 150.899 \\
\hline 280 & 329.15 & 321.50 & 46641.5 & 154.973 \\
\hline 290 & 336.80 & 333.23 & 49967.1 & 160.876 \\
\hline 298.15 & 342.79 & 342.62 & 52735.7 & 165.781 \\
\hline 300 & 344.12 & 344.78 & 53375.9 & 166.862 \\
\hline 325 & 361.49 & 372.97 & 62197.0 & 181.578 \\
\hline 350 & 379.53 & 400.40 & 71458.8 & 196.294 \\
\hline
\end{tabular}

presence of a magnetic lattice constraint upon the $\mathrm{Fe}$ in almandine that is not present in pyrope or in almandine at higher temperatures. Pyrope would be the preferred model

TABLE 4. Experimental heat capacities for almandine $(400-1000 \mathrm{~K})$.

\begin{tabular}{|c|c|c|c|c|c|}
\hline $\begin{array}{l}T \\
\mathrm{~K}\end{array}$ & $\begin{array}{c}\mathrm{Cp} \\
\mathrm{J} / \mathrm{mol} \mathrm{K}\end{array}$ & $\begin{array}{l}T \\
\mathbf{K}\end{array}$ & $\underset{J / \mathrm{mol} \mathrm{K}}{\mathrm{Cp}}$ & $\begin{array}{l}T \\
\mathrm{~K}\end{array}$ & $\begin{array}{c}\mathrm{Cp} \\
J / \mathrm{mol} \mathrm{K}\end{array}$ \\
\hline \multicolumn{2}{|c|}{ SERIES I } & 599.6 & 453.8 & 839.0 & 491.6 \\
\hline 420.0 & 403.1 & 619.5 & 459.5 & 848.0 & 492.7 \\
\hline 440.0 & 410.7 & 639.5 & 463.2 & \multicolumn{2}{|c|}{ SERIES V } \\
\hline 459.9 & 418.3 & 648.5 & 467.4 & 868.9 & 491.3 \\
\hline 479.9 & 424.6 & \multicolumn{2}{|c|}{ SERIES III } & 878.9 & 493.8 \\
\hline 499.8 & 431.4 & 659.4 & 466.7 & 888.9 & 494.1 \\
\hline 519.8 & 437.0 & 679.4 & 470.1 & 879.9 & 494.9 \\
\hline 539.7 & 442.2 & 699.3 & 470.6 & \multicolumn{2}{|c|}{ SERIES VI } \\
\hline 548.7 & 444.9 & 719.3 & 474.6 & 918.8 & 497.3 \\
\hline \multicolumn{2}{|c|}{ SERIES II } & 739.3 & 478.1 & 947.8 & 500.2 \\
\hline 519.8 & 435.7 & 748.2 & 479.1 & \multicolumn{2}{|c|}{ SERIES VII } \\
\hline 539.7 & 440.3 & \multicolumn{2}{|c|}{ SERIES IV } & 997.5 & 501.2 \\
\hline 559.7 & 444.9 & 819.1 & 487.1 & & \\
\hline 579.6 & 449.5 & 829.0 & 488.4 & & \\
\hline
\end{tabular}

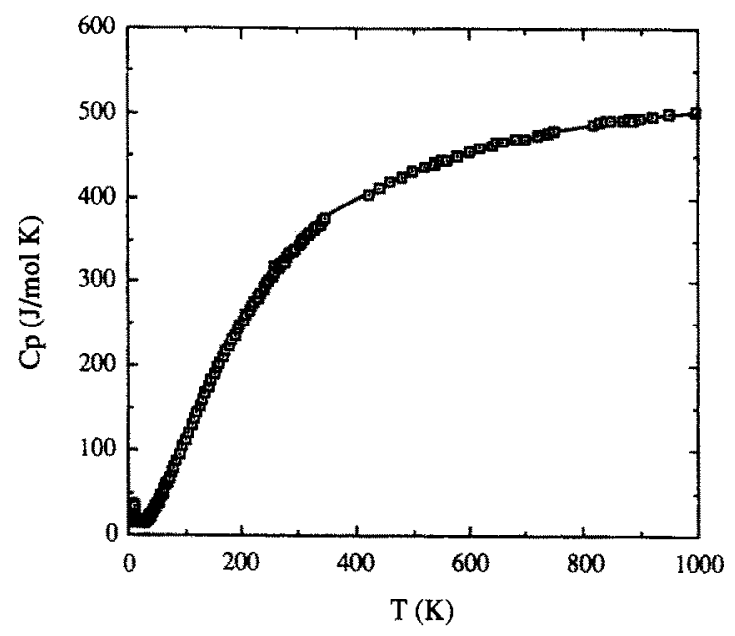

FIG. 2. Cp vs. $T$ for almandine from 6 to $1000 \mathrm{~K}$ showing the agreement between the DSC and adiabatic measurements.

presence of a magnetic lattice constraint upon the $\mathrm{Fe}$ in almandine that is not present in pyrope or in almandine at higher temperatures. Pyrope would be the preferred model component for almandine in corresponding states calculations at temperatures well above the magnetic transition. It is not clear, however, that it would be a good model in the region of the magnetic transition where the model calculation is applied. ARMBRUSTER et al. $(1991,1992)$ refined the structure at $100 \mathrm{~K}$ and above where the effects of the magnetic sublattice will be small and such refinements will not be definitive, as they will not reflect the effect of the magnetic lattice on the anisotropic vibration of $\mathrm{Fe}$ ions at very low temperatures, which may cause Fe to differ substantially from $\mathrm{Mg}$. Low-temperature conductivity measurements will be needed to determine whether or not electron delocalization or other electron disorder is a contributing factor and the degree to which the model calculation is correct. As the comparison remains useful for understanding the excess contributions to the total heat capacity, it will be retained with this caveat.

\section{Excess Contributions}

The lambda transition with a peak at $8.7 \mathrm{~K}$ represents ordering of the magnetic structure of almandine (Fig. 2). Below the transition temperature, the excess heat capacity is proportional to $T^{3}$ (ROBIE, 1987). Above the transition, the contribution cannot be modeled as a simple function of temperature. However, the total entropy resulting from the transition can be calculated from the spin-state as $\Delta S_{\text {mag }}$ $=n K \ln (2 S+1)$ (ULBRICH and WALDBAUM, 1976), where $S$ is the total spin quantum number of the magnetic atom and $n$ is the number of magnetic atoms in the formula unit. For almandine, the equation yields $\Delta S_{\text {mag }}=40.12 \mathrm{~J} / \mathrm{mol} \cdot \mathrm{K}$. The entropy contribution of the lattice can be obtained by integrating the model heat capacity as a function of temperature. The excess entropy is obtained by subtraction of the lattice contribution from the measured heat capacity (Fig. 4). As is typical of magnetic transitions, the excess entropy curve does not reach the value of the expected magnetic contribution until well above the transition temperature. 
TABLE 5. Smoothed thermodynamic functions for almandine $(298-1000 \mathrm{~K})$.

\begin{tabular}{|c|c|c|c|c|c|}
\hline $\begin{array}{l}T \\
\mathbf{K}\end{array}$ & $\underset{\mathrm{J} / \mathrm{mol} \cdot \mathrm{K}}{\mathrm{Cp}}$ & $\begin{array}{c}S_{T}-S_{0} \\
\mathrm{~J} / \mathrm{mol} \cdot \mathrm{K}\end{array}$ & $\begin{array}{c}\left(H_{T}^{\circ}-H_{298}^{\circ}\right) / T \\
\mathrm{~J} / \mathrm{mol} \cdot \mathrm{K}\end{array}$ & $\begin{array}{c}\left(G_{T}^{\circ}-H_{298}^{\circ}\right) / T \\
\mathrm{~J} / \mathrm{mol} \cdot \mathrm{K}\end{array}$ & $\begin{array}{l}\Delta G_{\mathfrak{q}_{\text {(meam) }}^{\circ}}^{\mathrm{kJ} / \mathrm{mol}} \\
\end{array}$ \\
\hline 298.15 & 342.8 & 342.6 & 0.000 & 342.6 & -4938.26 \\
\hline 300. & 344.2 & 344.7 & 2.118 & 342.6 & -4936.26 \\
\hline 350. & 374.7 & 400.2 & 53.278 & 346.9 & -4882.03 \\
\hline 400. & 397.6 & 451.8 & 94.946 & 356.8 & -4827.91 \\
\hline 450. & 415.8 & 499.7 & 129.62 & 370.1 & 4773.81 \\
\hline 500. & 430.9 & 544.3 & 159.02 & 385.3 & -4719.85 \\
\hline 550. & 443.7 & 586.0 & 184.33 & 401.7 & -4666.05 \\
\hline 600. & 454.7 & 625.1 & 206.41 & 418.7 & -4612.42 \\
\hline 650. & 464.3 & 661.9 & 225.89 & 436.0 & -4558.95 \\
\hline 700. & 472.6 & 696.5 & 243.22 & 453.4 & -4505.63 \\
\hline 750. & 479.8 & 729.5 & 258.76 & 470.7 & -4452.45 \\
\hline 800. & 486.0 & 760.6 & 272.77 & 487.9 & -4399.39 \\
\hline 850. & 491.2 & 790.2 & 285.47 & 504.8 & -4346.41 \\
\hline 900. & 495.5 & 818.4 & 297.03 & 521.4 & -4293.49 \\
\hline 950. & 498.9 & 845.3 & 307.57 & 537.8 & -4240.62 \\
\hline 1000 & 501.5 & 871.0 & 317.20 & 553.8 & -4187.75 \\
\hline
\end{tabular}

The excess entropy curve shown in Fig. 4 crosses the expected maximum contribution from the magnetic transition, rather than approaching it. This suggests that additional factors may be contributing to the entropy of almandine. A possible source for the excess is a Schottky thermal contribution from disordering of the iron d-electrons. This contribution would have a maximum value of $3 R \ln 2$ for almandine, representing three moles of iron in pseudocubic coordination. The experimental excess value is close to that expected from such a contribution; but this could be fortuitous, and more detailed spectral data are required to test this model.

\section{Entropy of Almandine}

At $298.15 \mathrm{~K}$, the measured entropy of almandine is 342.6 $\pm 1.4 \mathrm{~J} / \mathrm{mol} \cdot \mathrm{K}$, compared with estimates ranging from 284 to $342 \mathrm{~J} / \mathrm{mol} \cdot \mathrm{K}$; at $1000 \mathrm{~K}$, the measured entropy of almandine is $871.0 \pm 5.5 \mathrm{~J} / \mathrm{mol} \cdot \mathrm{K}$, compared with estimates

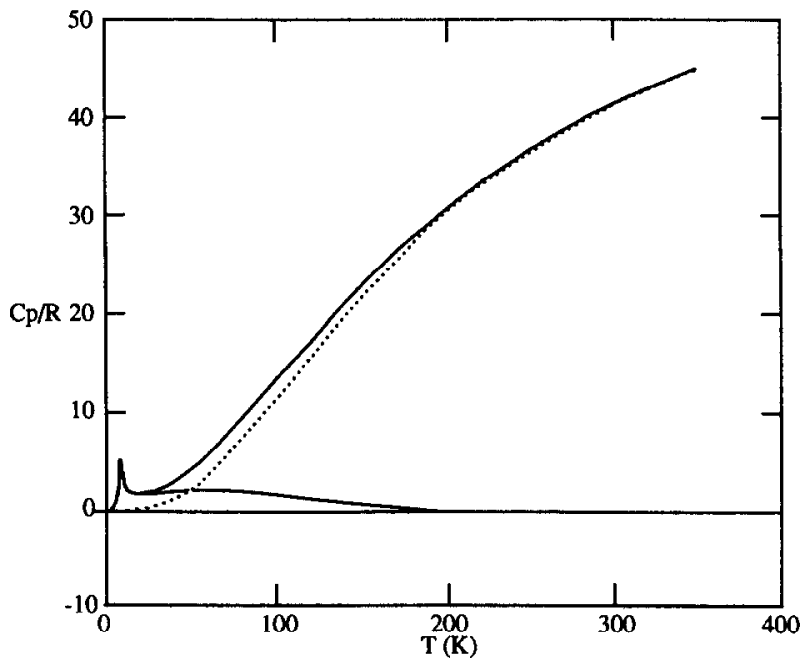

FIG. 3. Excess $\mathrm{Cp}$ of almandine. Solid line represents the measured Cp. Broken line is lattice as calculated from grossular, and the dashed curve shows excess $\mathrm{Cp}$ as a function of temperature. from 819 to $884 \mathrm{~J} / \mathrm{mol} \cdot \mathrm{K}$ (CHATILLON-COLINET et al., 1983; YAKOVLEV and VoZIANOVA, 1983; BERMAN, 1988; HolLAND and POWELL, 1990; see Table 7). Estimates of the entropy of almandine obtained from summation techniques or from experiments may have relatively large errors even at high temperatures.

\section{Gibbs Energy of Almandine}

The Gibbs energy of almandine may be calculated from the combination of entropy data with existing phase equilibrium data. The entropy function for almandine was extrapolated to higher temperatures using the technique of ROBINSON and HAAS (1983). These data were combined with experiments (Fig. 5) of BOHLEN et al. (1983a) for the equilibrium

$$
\begin{aligned}
\text { almandine }+ \text { rutile } & =\text { ilmenite }+ \text { sillimanite }+ \text { quartz } \\
\mathrm{Fe}_{3} \mathrm{Al}_{2} \mathrm{Si}_{3} \mathrm{O}_{12}+3 \mathrm{TiO}_{2} & =3 \mathrm{FeTiO}_{3}+\mathrm{Al}_{2} \mathrm{SiO}_{5}+2 \mathrm{SiO}_{2}(1)
\end{aligned}
$$

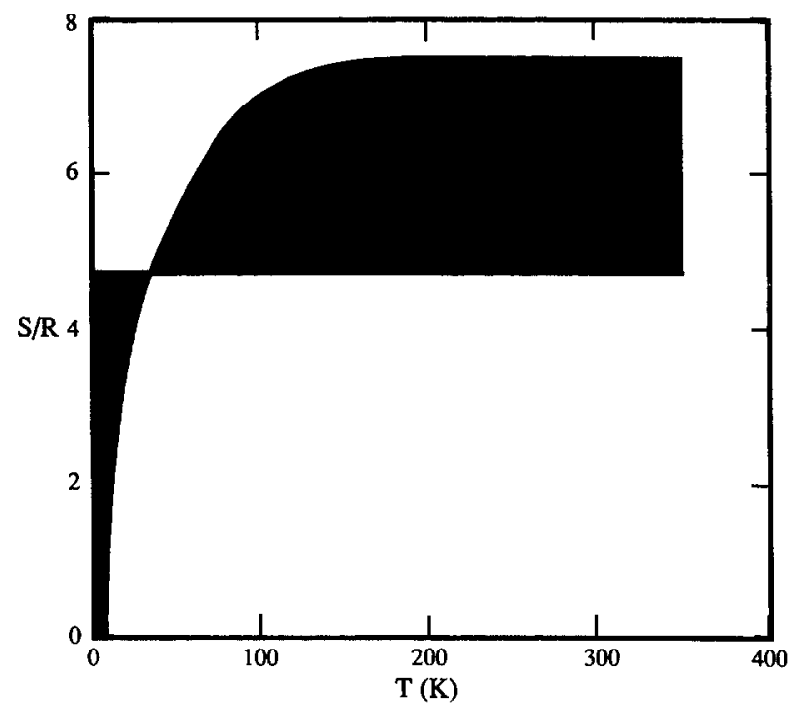

FIG. 4. Excess entropy as a function of temperature. The straight line represents the expected magnetic contribution. 


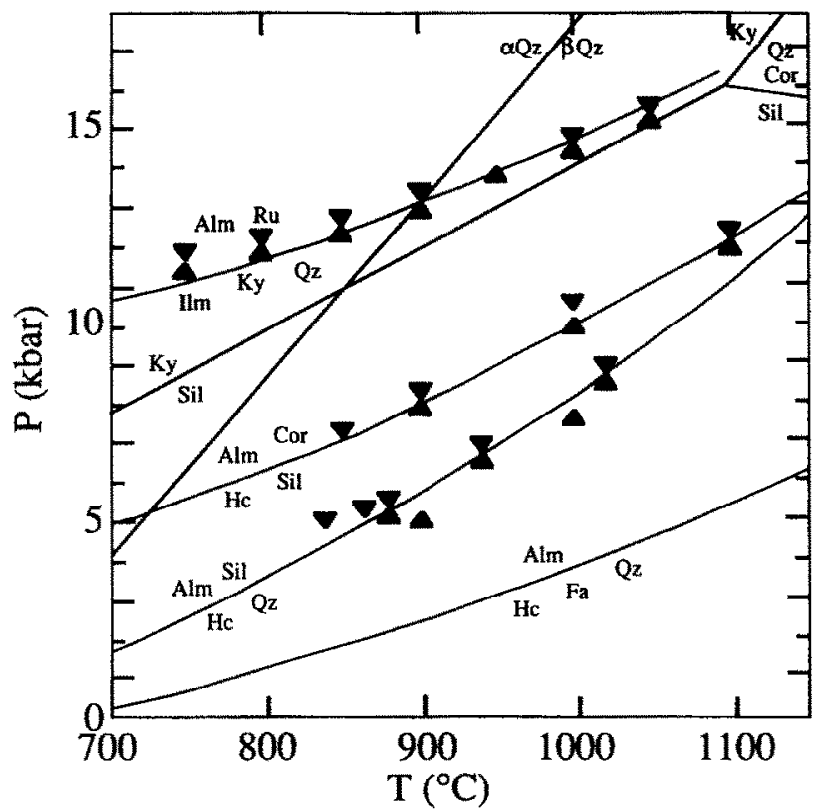

FIG. 5. Calculated and experimental locations for Reaction 1 (BOHLEN et al., 1983a), Reaction 2 (BOHLEN et al., 1983b), Reaction 3 (SHULTERS and BOHLEN, 1989), and the $\alpha-\beta$ quartz transition (COHEN and KLEMENT, 1967). The calculated stability field for quartz + corundum, the kyanite-sillimanite transition, and Reaction 5 are also shown.

and existing thermodynamic data for the other phases, except sillimanite, to calculate the $\Delta G_{f}^{\circ}$ and $\Delta H_{f}^{\circ}$ for almandine (Table 6), yielding $-4938.26 \mathrm{~kJ} / \mathrm{mol}$ and $-5261.3 \mathrm{~kJ} / \mathrm{mol}$, respectively. The uncertainties in these values were estimated from the maximum misfit to Reaction 1 as $\pm 0.7 \mathrm{~kJ} / \mathrm{mol}$. Gibbs energy values are reported to a greater precision than this in order to allow more precise replication of the calculations presented (cf. ROBIE et al., 1979).

The entropy, enthalpy, and Gibbs energy of almandine estimated here are compared with previous estimates from the literature for almandine at 298.15 and $1000 \mathrm{~K}$ in Table 7. Literature data may be separated into two kinds, those using old experiments and an estimated entropy for almandine, and those using our entropy data and the high-pressure experiments of BOHLEN et al. (1983a); the former group of estimates is highly disparate from the latter group (Table 7). The smaller differences within the latter group may be traced to differences in data used for the volumes, entropies, and Gibbs energies of the phases involved in the reaction.

In order to obtain a precise set of thermodynamic data for sillimanite relative to quartz and corundum, we have combined calculations using reversals (Fig. 5) for the following experimentally determined reactions:

$$
\begin{aligned}
\text { almandine }+ \text { sillimanite } & =\text { hercynite }+ \text { quartz } \\
\mathrm{Fe}_{3} \mathrm{Al}_{2} \mathrm{Si}_{3} \mathrm{O}_{12}+2 \mathrm{Al}_{2} \mathrm{SiO}_{5} & =3 \mathrm{FeAl}_{2} \mathrm{O}_{4}+5 \mathrm{SiO}_{2}
\end{aligned}
$$

(BOHLEN et al., 1986); and

almandine + corundum $=$ hercynite + sillimanite

$$
\mathrm{Fe}_{3} \mathrm{Al}_{2} \mathrm{Si}_{3} \mathrm{O}_{12}+5 \mathrm{Al}_{2} \mathrm{O}_{3}=3 \mathrm{FeAl}_{2} \mathrm{O}_{4}+3 \mathrm{Al}_{2} \mathrm{SiO}_{3}
$$

(SHULTERS and BOHLEN, 1989) to derive a $\Delta G_{i, 298}^{\circ}$ of -1.41 $\mathrm{kJ} / \mathrm{mol}$ for the reaction

$$
\begin{aligned}
\text { corundum }+\beta \text {-quartz } & =\text { sillimanite } \\
\mathrm{Al}_{2} \mathrm{O}_{3}+\mathrm{SiO}_{2} & =\mathrm{Al}_{2} \mathrm{SiO}_{5} .
\end{aligned}
$$

A similar calculation was made by SHULTERS and BOHLEN (1989) from their data, yielding a similar $\Delta G_{f, 298}^{\circ}(-0.7 \mathrm{~kJ} /$ mol) for Reaction 4 when extrapolated from their calculation at high temperatures.

The $\Delta G_{i, 298}^{0}$ value derived for sillimanite from Reactions 2,3 , and 4 (Table 6 ) differs up to $3 \mathrm{~kJ} / \mathrm{mol}$ from that previously reported (e.g., by $-2.6 \mathrm{~kJ} / \mathrm{mol}$, HELGESON et al., $1978 ;-0.6 \mathrm{~kJ} / \mathrm{mol}$, ROBIE et al., $1978 ;-3.1 \mathrm{~kJ} / \mathrm{mol}$, RoBINSON et al., 1983; $-2.2 \mathrm{~kJ} / \mathrm{mol}$, ANOVITZ and ESSENE, 1987, and MOECHER et al., $1988 ;-3.0 \mathrm{~kJ} / \mathrm{mol}$, TOPOR et al., 1989; and $-0.5 \mathrm{~kJ} / \mathrm{mol}$, HEMINGWAY et al., 1991). Acceptance of this datum requires revisions of the $\Delta G_{i, T}^{\circ}$ data for the aluminous silicates but is necessary if the various tightly reversed experiments on the stability of almandine are to be fitted to an internally consistent data set. In addition, as Reactions 2 and 3 can be added to derive the oxide formation Reaction 4 , they provide a necessary tight constraint as the Gibbs energy of one of the aluminum silicates must be known in order to derive those of the other two from the polymorphic transition reactions. With the smaller $\Delta G_{f, 298}^{0}$ value for Reaction 4, a stability field for quartz + corundum may be calculated at ca. $16 \mathrm{kbar}$ and $T>1100^{\circ} \mathrm{C}$ (Fig. 5). The reliability of this constraint can be evaluated by comparing the calculated position of the kyanite-bearing equivalent of Reaction 4 with that located experimentally by PETERSON and NEWTON (1990). Their experiments place this reaction between 7.75 and $8.0 \mathrm{~kb}$ at $815^{\circ} \mathrm{C}$. The data used here yield $8.0 \mathrm{~kb}$ at this same temperature, well within the experimental and thermodynamic uncertainty. As the calculated location of Reaction 4 still retains large uncertainties, it should be investigated by further experimental studies.

Thermodynamic data for various phases in the system $\mathrm{CaO}-\mathrm{FeO}-\mathrm{Fe}_{2} \mathrm{O}_{3}-\mathrm{Al}_{2} \mathrm{O}_{3}-\mathrm{SiO}_{2}-\mathrm{H}_{2} \mathrm{O}$ were recalculated with the method of ANOVITZ and ESSENE (1987), including the more recent data of HEMINGWAY ( 1987) on quartz (Table 6). Calculations of the phase equilibria with these data compared with the reversals are shown in Fig. 5. Good agreement is generally achieved between experiment and calculation, except for Reaction 1, where a difference in slope is found (Fig. 5 ). This reaction is sensitive to small changes in volume and entropy data (ESSENE, 1989), and the disagreement may be caused by small errors in the calculation of the effects of pressure and temperature on these parameters. For instance, if the thermal expansivity of ilmenite is estimated from hematite, rather than from the direct measurements of WECHLER and PREWITT (1984) used here, the calculated slope is in agreement with the reversals. There do not, however, appear to be obvious errors in the data of WECHLER and PREWITT (1984); thus, we have retained these data in our calculation, although this yields a slightly poorer fit to Reaction 1 .

An evaluation of the reliability of the data presented in Table 6 may be obtained by comparison with the experiments of HARLOV and NEWTON (1992) on the following reaction:

$$
\begin{aligned}
\text { almandine }+\mathrm{O}_{2} & =\text { magnetite }+ \text { kyanite }+ \text { quartz } \\
2 \mathrm{Fe}_{3} \mathrm{Al}_{2} \mathrm{Si}_{3} \mathrm{O}_{12}+\mathrm{O}_{2} & =2 \mathrm{Fe}_{3} \mathrm{O}_{4}+2 \mathrm{Al}_{2} \mathrm{SiO}_{5}+4 \mathrm{SiO}_{2} .
\end{aligned}
$$


TABLE 6. Thermodynamic data set for selected phases in the system $\mathrm{Ca}-\mathrm{Fe}-\mathrm{Al}-\mathrm{Si}-\mathrm{O}-\mathrm{H}$.

\begin{tabular}{|c|c|c|c|c|c|c|c|c|c|}
\hline Phase & $a b b$ & $V_{298}^{\circ}$ & ref. & $\mathbf{A}$ & B & ref. & $\mathrm{C}$ & $\mathrm{D}$ & ref. \\
\hline hercynite & hc & 40.75 & (1) & 0.14 & 2.9 & $(10)$ & 0.48 & 0.00 & (17) \\
\hline sillimanite & sil & 50.02 & (6) & 1.30 & 1.4 & (7) & 0.76 & -2.00 & (8) \\
\hline kyanite & ky & 44.21 & (6) & 2.51 & -0.0 & (7) & 0.79 & -11.00 & (8) \\
\hline corundum & cor & 25.57 & (1) & 2.15 & 4.1 & (2) & 0.35 & 0.03 & (3) \\
\hline quartz $\left(\alpha, T<573^{\circ} \mathrm{C}\right)$ & $\alpha \mathbf{q z}$ & 22.69 & (1) & 0.42 & 112.9 & (2) & 2.26 & -7.47 & (5) \\
\hline quartz $\left(\alpha, T>573^{\circ} \mathrm{C}\right)$ & $\alpha \mathbf{q z}$ & 23.24 & (4) & 3.27 & -14.7 & (4) & 2.26 & -7.47 & (5) \\
\hline quartz $(\beta)$ & $\beta \mathrm{qz}$ & 23.74 & (16) & 0.37 & -3.28 & $(2)$ & 2.26 & -7.47 & (5) \\
\hline fayalite & $\mathrm{fa}$ & 46.39 & (9) & 3.16 & 0.35 & (6) & 0.91 & 0.00 & (6) \\
\hline ferrosilite & fs & 32.96 & (10) & 1.43 & 11.25 & (10) & 0.99 & -5.03 & $(3,11)$ \\
\hline magnetite $(\alpha)$ & $\alpha \mathrm{mt}$ & 44.52 & (1) & 3.18 & 12.26 & (2) & 0.57 & -0.41 & (3) \\
\hline magnetite $(\beta)$ & $\beta \mathrm{mt}$ & 44.52 & (1) & 3.18 & 12.26 & (2) & 0.57 & -0.41 & (3) \\
\hline hematite $(\alpha)$ & $\alpha \mathrm{hm}$ & 30.27 & (1) & 3.77 & 0.47 & (6) & 0.48 & 0.07 & (18) \\
\hline hematite $(\beta)$ & $\beta \mathrm{hm}$ & 30.27 & (1) & 3.77 & 0.47 & (6) & 0.48 & 0.07 & (18) \\
\hline almandine & alm & 115.11 & (12) & 0.23 & 1.8 & (10) & 0.57 & 0.00 & (13) \\
\hline
\end{tabular}

References: (1) RoBIE et al. (1978), (2) SKINNER (1966), (3) BIRCH (1966), (4) fit to $\alpha$-b transition, (5) OLINGER and HALLECK (1976), (6) ROBINSON et al. (1983), (7) WINTER and GHOSE (1979), (8) BRACE et al. (1969), (9) E. J. Essene et al. (unpubl. data), (10) L. M. Anovitz and Haas (unpubl. data), (11) BASS and WEIDNER (1984), (12) this study, (13) ANOVITZ and ESSENE (1987), (14) VAIDYA et al. (1973), (15) LIEBERMAN and RINGWOOD (1976), (16) fit to high-temperature volume data, (17) WANG and SIMMONS (1972), and (18) WILBURN et al. (1978)

Notes: Volume in $\mathrm{cm}^{3} / \mathrm{mol}$. \% Expansion $=\mathrm{A} * 10^{-3} *(T-293)+\mathrm{B} * 10^{-7} *(T-293)^{2}(T \mathrm{~K})$. \% Compressibility $=\mathrm{C} * 10^{-1} * \mathrm{P}+\mathrm{D} * 10^{-4} * \mathrm{P}^{2}$ (P kbar)

\begin{tabular}{|c|c|c|c|c|c|c|c|c|c|}
\hline Phase & $S_{298}^{\circ}$ & ref. & $\mathbf{E}$ & $\mathbf{F}$ & $\mathrm{G}$ & $\mathbf{H}$ & ref. & $\Delta G_{298}^{\circ}$ & ref. \\
\hline hercynite & 119.60 & (12) & -103.400 & 143.759 & 49.965 & -94.917 & (11) & -1838.26 & $(5$ \\
\hline sillimanite & 95.80 & (4) & 164.471 & 33.575 & -0.010 & -46.069 & (1) & -2439.63 & \\
\hline kyanite & 82.40 & (4) & 181.138 & 27.067 & -2.278 & -48.565 & (1) & -2443.66 & \\
\hline corundum & 50.92 & (1) & 153.489 & 1.956 & -9.023 & -20.267 & (1) & -1582.33 & \\
\hline quartz $\left(\alpha, T<573^{\circ} \mathrm{C}\right)$ & 41.46 & (1) & 66.501 & 31.057 & -4.673 & -3.656 & (10) & -856.29 & (10) \\
\hline quartz $\left(\alpha, T>573^{\circ} \mathrm{C}\right)$ & 41.46 & (1) & 145.299 & -20.897 & -16.818 & 2.218 & (1) & -856.21 & (10) \\
\hline quartz $(\beta)$ & 37.44 & (13) & 59.296 & 9.933 & -0.090 & 0.152 & (1) & -855.89 & \\
\hline fayalite & 152.10 & (2) & 58.015 & 71.155 & 20.576 & -58.404 & (6) & -1377.14 & \\
\hline ferrosilite & 95.80 & (8) & 157.837 & 6.416 & -10.705 & -7.883 & (8) & -1115.83 & \\
\hline magnetite $(\alpha)$ & 146.01 & (2) & -2480.704 & 1417.774 & 485.735 & -539.311 & (2) & -1014.14 & \\
\hline magnetite $(\beta)$ & 80.50 & (13) & -79.901 & 58.295 & 76.874 & -72.569 & (2) & -1019.46 & \\
\hline hematite $(\alpha)$ & 87.48 & (2) & -711.859 & 439.712 & 156.435 & -197.947 & (2) & -745.27 & \\
\hline hematite $(\beta)$ & 28.41 & (13) & -551.204 & 159.620 & 180.411 & -327.895 & (2) & -752.79 & \\
\hline almandine & 342.60 & (9) & 862.944 & -82.878 & -88.746 & 16.967 & (9) & -4938.26 & \\
\hline
\end{tabular}

References: (1) ROBIE et al. (1978), (2) ROBINSON et al. (1983), (3) fit to $\alpha-\beta$ transition, (4) RoBIE and HEMINGWAY (1984), (5) this study, (6) RoBIE et al. (1982), (7) ANOvitZ and ESSENE (1987) reevaluated, (8) BOHLEN et al. (1983b), (9) METZ et al. (1983), (10) HEMINGWAY, 1987, (11) L. M. Anovitz et al. (unpubl. data), (12) L. M. Anovitz et al. (unpubl. data), and (13) fit to high-temperature data.

Notes: Entropy in $\mathrm{J} / \mathrm{mol} \cdot \mathrm{K}$, Gibbs energy in $\mathrm{kJ} / \mathrm{mol}$. $\mathrm{Cp}=\mathrm{E}+\mathrm{F} * 10^{-3} * T+\mathrm{G} * 10^{2} * T^{-1 / 2}+\mathrm{H} * 10^{-5} * T^{-2}(T \mathrm{~K})$.

TABLE 7. Comparisons of thermodynamic data for almandine.

\begin{tabular}{|c|c|c|c|c|c|c|}
\hline $\begin{array}{c}S_{298}^{o} \\
\mathrm{~J} / \mathrm{mol} \mathrm{K}\end{array}$ & $\begin{array}{l}\Delta G_{\mathrm{f}, 298}^{\mathrm{o}} \\
\mathrm{kJ} / \mathrm{mol}\end{array}$ & $\begin{array}{l}\Delta H_{\mathrm{f}, 298}^{\circ} \\
\mathrm{kJ} / \mathrm{mol}\end{array}$ & $\underset{\mathrm{J} / \mathrm{mol} \mathrm{K}}{S_{\mathrm{i}}^{\circ}}$ & $\begin{array}{l}\Delta G_{\mathrm{f}, 1000}^{\circ} \\
\mathrm{kJ} / \mathrm{mol}\end{array}$ & $\begin{array}{l}\Delta H_{\mathfrak{f}, 1000}^{\circ} \\
\mathrm{kJ} / \mathrm{mol}\end{array}$ & \\
\hline 321. & -4969. & -5322 . & - & - & - & (1) \\
\hline 286. & -4989. & -5329. & - & - & - & (2) \\
\hline 340. & -4956. & -5280 . & 839. & - & - & (3) \\
\hline 331. & - & - & 884. & -4210 & -5276 & (4) \\
\hline 284. & -4979. & -5319. & 819. & -4188 & -5321 & (5) \\
\hline 286. & -4970. & -5310. & 817. & - & - & (6) \\
\hline 338. & -4951. & -5275 & - & - & - & (7) \\
\hline 339.9 & -4941.7 & -5265.5 & 867.9 & -4198.5 & -5277.6 & (8) \\
\hline - & -4944.0 & -5267.8 & - & - & - & (9) \\
\hline 342.0 & -4944.7 & -5267.8 & - & - & - & (10) \\
\hline- & - & -5272.0 & - & - & - & (11) \\
\hline 342.6 & -4938.3 & -5261.3 & 871.0 & -4187.75 & -5268.0 & (12) \\
\hline
\end{tabular}

References: (1) FED'KIN (1970), (2) ZEN (1973), (3) KARPOV et al. (1977), (4) CHATILLON-COLINET et al. (1983), (5) YAKOVLEV and VOZIANOVA (1983), (6) Bhattacharya (1986), (7) CHATTERJEe (1987), (8) BERMAN (1988), (9) WOODLAND and WOOD (1989), (10) HOLLAND and POWEll (1990), (11) HARLOV and NEWTON (1992), and (12) this work. 
Uncorrected for solid solutions in the run products, the experiments place Reaction 5 between 20 and $23 \mathrm{~kb}$ at $650^{\circ} \mathrm{C}$, 22 and $22.5 \mathrm{~kb}$ at $700^{\circ} \mathrm{C}, 25.5$ and $26 \mathrm{~kb}$ at $800^{\circ} \mathrm{C}$, and 28 and $29 \mathrm{~kb}$ at $900^{\circ} \mathrm{C}$. Uncertainties are given as $\pm 0.2 \mathrm{~kb}$ and $\pm 10^{\circ} \mathrm{C}$ (which is equivalent to an additional $\pm 0.3 \mathrm{~kb}$ from the slope of the reaction ). Our calculations place this reaction at $20.7 \mathrm{~kb}$ at $650^{\circ} \mathrm{C}, 21.9 \mathrm{~kb}$ at $700^{\circ} \mathrm{C}, 24.5 \mathrm{~kb}$ at $800^{\circ} \mathrm{C}$, and $27.1 \mathrm{~kb}$ at $900^{\circ} \mathrm{C}$. These calculations are in good agreement with the experimental data at the lower temperatures but yield somewhat low pressures at higher temperatures. Corrections for solid solutions in the almandine, which appears to occur as a FIG component $\left.\left(\mathrm{Fe}^{3+}\right)_{3}\left(\mathrm{Al}, \mathrm{Fe}^{3+}\right)_{2} \mathrm{Al}_{3} \mathrm{O}_{12}\right)$, as well as the skiagite component suggested by HARLOV and NEWTON (1992), and in kyanite and magnetite, assuming ideal molecular mixing, yield a $+0.2 \mathrm{~kb}$ correction in the location of the endmember reaction. If present, a maghemite component would further reduce the pressure of the endmember reaction.

The remaining differences between our calculated position for Reaction 5 and that located expcrimentally by HARLOV and NEwTON (1992) appear to be due to the slope of the reaction. This also appears to be the primary reason for the difference in the value for $\Delta G_{\mathrm{f}, 298}^{0}$ calculated here and by Harlov and Newton (Table 7). These differences could be relieved by decreasing the entropy or increasing the volume for almandine used here (or vice versa for magnetite + kyanite + quartz). As this is the opposite of the change in almandine necessary to better fit Reaction 1, a major change is considered unlikely; but additional data on the thermal expansivity, compressibility, and/or high-temperature heat capacity of the phases involved are needed.

The experiments of HARLOV and NEWTON (1992) may also reflect progress of the following reaction:

$$
\text { almandine }+ \text { hematite }=\text { magnetite }+ \text { kyanite }+ \text { quart } z
$$

$2 \mathrm{Fe}_{3} \mathrm{Al}_{2} \mathrm{Si}_{3} \mathrm{O}_{12}+6 \mathrm{Fe}_{2} \mathrm{O}_{3}$

$$
=6 \mathrm{Fe}_{3} \mathrm{O}_{4}+2 \mathrm{Al}_{2} \mathrm{SiO}_{5}+4 \mathrm{SiO}_{2} \text {. }
$$

Reactions 5 and 6 would coincide in $P-T-f_{\mathrm{O}_{2}}$ space only if magnetite and hematite maintain exactly the same compositions in both capsules. The possibility of variable maghemite solid solution in the magnetites of each capsule needs to be evaluated. More careful BSE, EMPA, and XRD studies on the run products are needed to characterize the effects of any differential solid solutions in run products and starting materials from both capsules.

\section{PHASE EQUILIBRIA}

Thermodynamic data for almandine may be used to calculate phase equilibria in the system Fe-Al-Si-O. Previous calculations (e.g., FROESE, 1973) were performed with thermodynamic parameters estimated or obtained from phase equilibrium experiments. The sensitivity of solid-solid reactions to small changes in Gibbs energy permits the calculation of accurate Gibbs energy values, provided accurate thermodynamic data are available for the phases involved. This same sensitivity, however, makes calculation of the $P$ $T$ locations of solid-solid equilibria imprecise unless they are based on other experimentally reversed solid-solid phase equilibria, as in this paper. HAAS and FISHER ( 1976) described a procedure to extract best-fit thermodynamic parameters from large data sets using a least-squares model. ROBINSON et al. (1983) applied this technique to a variety of iron-bearing systems, and L. M. Anovitz et al. (unpubl. data) used the program in the Fe-Al-Si-C-O-H system. In this study, we shall restrict our consideration to anhydrous equilibria defining the $P-T-f_{\mathrm{O}_{2}}$ stability of almandine. Such equilibria have many potential applications in metamorphic petrology.

\section{Sources of Data}

The thermodynamic data for the phases considered are listed in Table 6. To preserve internal consistency, we accepted the thermodynamic values of RoBINSON et al. (1983) for the phases quartz, corundum, magnetite, hematite, and fayalite. Calculation of the stability of almandine requires thermodynamic data for hercynite $\left(\mathrm{FeAl}_{2} \mathrm{O}_{4}\right)$. The $S_{298}^{0}$ for hercynite reported by KING (1955) is based on heat capacity measurements between 50 and $298 \mathrm{~K}$ and does not include the contribution from the magnetic transition at $7.5 \mathrm{~K}$ (ROTH, 1964). Although many measurements have been made for $\Delta G_{\mathrm{f}}^{0}$ and $\Delta H_{\mathrm{f}}^{0}$ of hercynite at high temperatures (e.g., PILLAY et al., 1960; RESUKINA et al., 1963; BROKLOFF, 1964; MCLEAN and WARD, 1966), uncertainty about the composition and the degree of cation ordering of the hercynite and the lack of complete $\mathrm{Cp}$ data complicates their application. For this paper, we have adopted the entropy data given by L. M. Anovitz et al. ( unpubl. data) for hercynite in combination with phase equilibrium data (Fig. 5) on Reaction 2 to calculate $\Delta G_{f, 298}^{0}$ for hercynite.

The $\alpha-\beta$ phase transition in quartz presents a problem for thermodynamic calculations at high pressures. Calculation of phase equilibria involving quartz at high pressures and temperatures requires thermodynamic data for $\alpha$-quartz at temperatures beyond its stability range at 1 bar. A leastsquares procedure was used to derive these data for $\alpha$-quartz by constraining the Gibbs energy of $\alpha$-quartz to equal that of $\beta$-quartz along the transition reported by COHEN and KLEMENT (1967). This procedure is not entirely satisfactory but it does reproduce the experimental data. No reversal points in the field of stability for $\alpha$-quartz were used in Gibbs energy calculations for almandine.

\section{Method of Calculation}

Phase equilibrium calculations were performed using the program THERMO, a modified version of the program EQUill (Slaughter et al., 1976; Perkins et al., 1987). This program permits calculation of the Gibbs energy of a reaction as a function of pressure and temperature with correction for thermal expansion and compressibility. Entropy and volume data were fit with appropriate equations, and consistent $\Delta G_{f, 298}^{0}$ values were derived for all phases considered as described in the preceding text. This permits the calculation of Gibbs energies for reactions that have not been investigated experimentally.

\section{Pressure and Temperature Stability of Almandine}

Above $3.3 \mathrm{kbar}$, the upper stability of almandine is limited by the following equilibrium: 


$$
\begin{aligned}
\text { almandine } & =\text { hercynite }+ \text { fayalite }+ \text { quartz } \\
\mathrm{Fe}_{3} \mathrm{Al}_{2} \mathrm{Si}_{3} \mathrm{O}_{12} & =\mathrm{FeAl}_{2} \mathrm{O}_{4}+\mathrm{Fe}_{2} \mathrm{SiO}_{4}+2 \mathrm{SiO}_{2} .
\end{aligned}
$$

This reaction may be calculated from the thermodynamic data for these phases listed in Table 6 . The endmember reaction is located at $570^{\circ} \mathrm{C}$ at 1 bar and has a slope of +17 bars $/{ }^{\circ} \mathrm{C}$ (Fig. 6). The experiments of HsU (1968) also constrain the position of Reaction 7. Hsu determined the stability of almandine on the QFM buffer at $0.5,1,2$, and $3 \mathrm{kbar}$ by the following oxidation reaction:

$$
\begin{array}{r}
\text { almandine }+\mathrm{O}_{2}=\text { magnetite }+ \text { hercynite }+ \text { quartz } \\
3 \mathrm{Fe}_{3} \mathrm{Al}_{2} \mathrm{Si}_{3} \mathrm{O}_{12}+\mathrm{O}_{2}=2 \mathrm{Fe}_{3} \mathrm{O}_{4}+3 \mathrm{FeAl}_{2} \mathrm{O}_{4}+9 \mathrm{SiO}_{2} .
\end{array}
$$

Reaction 7 may be calculated when Reaction 8 is combined with

$$
\begin{aligned}
& \text { fayalite }+\mathrm{O}_{2}=\text { magnetite }+ \text { quartz } \\
& \mathrm{Fe}_{2} \mathrm{SiO}_{4}+\mathrm{O}_{2}=\mathrm{Fe}_{3} \mathrm{O}_{4}+\mathrm{SiO}_{2},
\end{aligned}
$$

after correction for the effects of the mutually reduced activities of $\mathrm{FeAl}_{2} \mathrm{O}_{4}$ in hercynite and $\mathrm{Fe}_{3} \mathrm{O}_{4}$ in magnetite in the experimental materials. TURNOCK and EUGSTER (1962) experimentally constrained the position of the hercynite-magnetite solvus, and YAKOVLEV and VOZIANOVA (1983) used these experiments to model the $a / X$ relations of hercynitemagnetite solid solutions at $600-860^{\circ} \mathrm{C}$. When Reaction 8 is corrected for the reduced spinel activities, the calculated lccation of Reaction 7 agrees with the experiments of Hsu (1968) to within $10 \mathrm{~K}$.

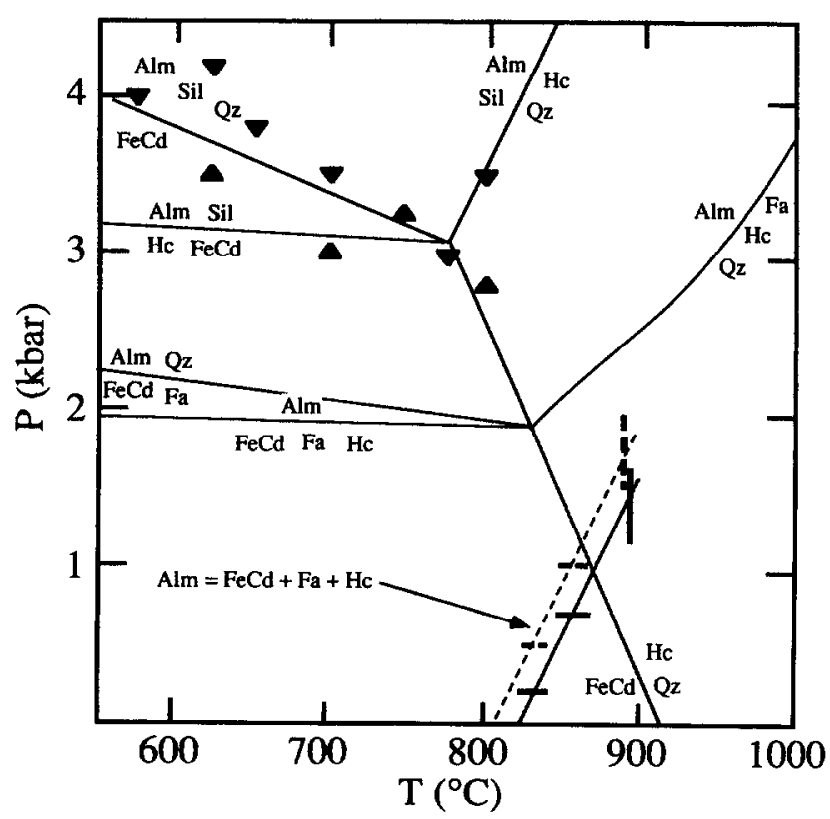

FIG. 6. Provisional $P-T$ phase diagram for the relative stabilities of almandine, hercynite, and Fe-cordierite. Triangles show experimental reversal brackets for the reaction $\mathrm{FeCd}=\mathrm{Alm}+\mathrm{Sil}+\mathrm{Qz}$ (RICHARDSON, 1968; WEISBROD, 1973). The experimental reversals shown as solid bars for Reaction 9 , Alm $=\mathrm{Hc}+\mathrm{Fa}+\mathrm{FeCd}$, have been corrected for the effects of reduced activities of $\mathrm{FeAl}_{2} \mathrm{O}_{4}$. The solid curve shows the location of the endmember reaction suggested by these data. The dashed bars and line are the uncorrected data. These results disagree strongly with the results of our calculation.

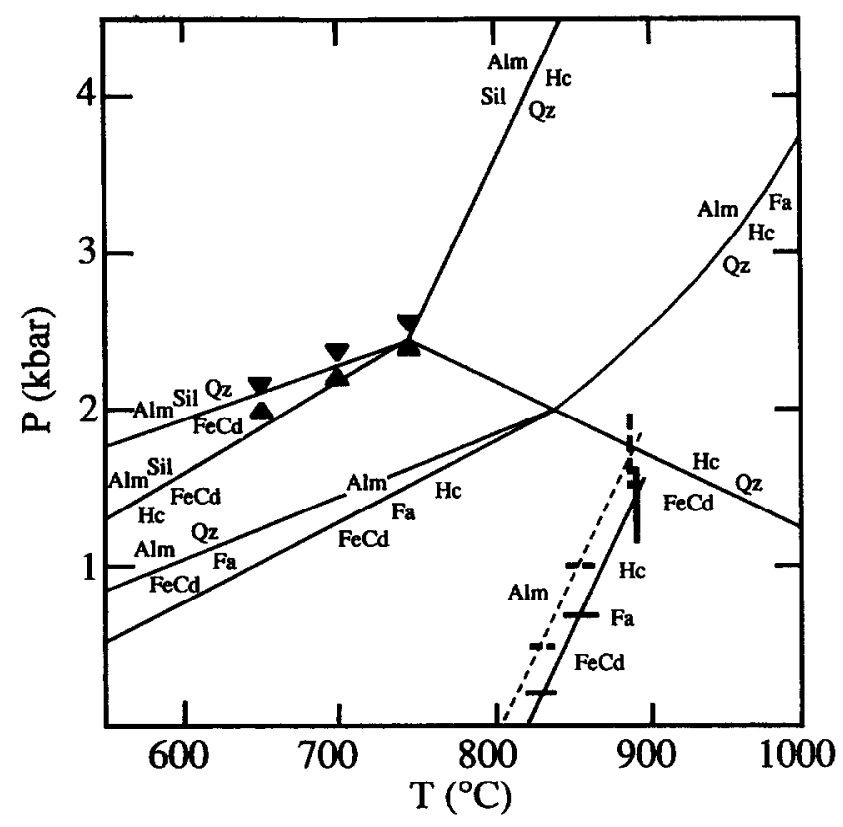

FIG. 7. Provisional $P-T$ phase diagram for the relative stabilities of almandine, hercynite, and Fe-cordierite. Triangles show experimental reversal brackets for the reaction $\mathrm{FeCd}=\mathrm{Alm}+\mathrm{Sil}+\mathrm{Qz}$ (MukHOPADHYAY et al., 1991). The experimental reversals shown as solid bars for Reaction 9, Alm = Hc + Fa $+\mathrm{FeCd}$, have been corrected for the effects of reduced activities of $\mathrm{FeAl}_{2} \mathrm{O}_{4}$. The solid curve shows the location of the endmember reaction suggested by these data. The dashed bars and line are the uncorrected data. These results disagree strongly with the results of our calculation.

\section{Reactions Involving Fe-cordierite}

Below ca. $3.3 \mathrm{kbar}$, the upper stability of almandine is governed by reactions involving Fe-cordierite (Figs. 6 and 7). Hsu (1968) experimentally determined the position of the following reaction:

almandine $=$ hercynite + fayalite + Fe-cordierite

$5 \mathrm{Fe}_{3} \mathrm{Al}_{2} \mathrm{Si}_{3} \mathrm{O}_{12}$

$$
=\mathrm{FeAl}_{2} \mathrm{O}_{4}+5 \mathrm{Fe}_{2} \mathrm{SiO}_{4}+2 \mathrm{Fe}_{2} \mathrm{Al}_{4} \mathrm{Si}_{5} \mathrm{O}_{18},
$$

buffered on QFM in the presence of excess $\mathrm{H}_{2} \mathrm{O}$ (Figs. 6 and 7). The phase Fe-cordierite (sekaninaite) has been excluded from quantitative analysis of the system Fe-Al-Si-O because no accurate thermodynamic data are available for it. Estimation of accurate thermodynamic properties from phase equilibrium experiments involving cordierite is difficult as a result of uncertainties in the roles of water and order/disorder. There are a plethora of models for the stability of cordierite, but no consensus has been reached yet on the possible effects of $\mathrm{H}_{2} \mathrm{O}$, which has been either arbitrarily modeled with an ideal ionic model (HOLDAWAY and LEE, 1977; LEE and HOLDAWAY, 1977; NEWTON and WOOD, 1979; LONKER, 1981; MARTIGNOLE and SISI, 1981; ARANOVICH and PODLESSKII, 1983; BHATTACHARYA and SEN, 1985; BHATTACHARYA, 1986) or neglected entirely (e.g., CURRIE, 1971; HENSON, 1971, 1972; HENSON and GREEN, 1973; HUTCH. EON et al., 1974; THOMPSON, 1976a,b; BHATTACHARYA et al., 1988). Until an experimentally based activity model for cordierites in the system $\mathrm{Fe}_{2} \mathrm{Al}_{4} \mathrm{Si}_{5} \mathrm{O}_{18}-\mathrm{H}_{2} \mathrm{O}$ becomes available, 
the exact locations and slopes of reactions involving Fe-cordierite cannot be calculated.

Despite the uncertainties in the thermodynamic properties of cordierite, the phase relations between almandine and cordierite should be examined, if only semiquantitatively, because of the important role these equilibria play in a number of geologic terranes. A provisional low-pressure phase diagram for the relative stabilities of almandine and Fe-cordierite (Figs. 6 and 7) may be derived from available experiments. The reaction

almandine + sillimanite + quartz $=$ Fe-cordierite

$$
2 \mathrm{Fe}_{3} \mathrm{Al}_{2} \mathrm{Si}_{3} \mathrm{O}_{12}+4 \mathrm{Al}_{2} \mathrm{SiO}_{5}+5 \mathrm{SiO}_{2}=3 \mathrm{Fe}_{2} \mathrm{Al}_{4} \mathrm{Si}_{5} \mathrm{O}_{18}
$$

has been studied at $2-4 \mathrm{~kb}$ and $550-800^{\circ} \mathrm{C}$ by a number of authors (RICHARDSON, 1968; WEISBROD, 1973; HOLDAWAY and LEE, 1977; SHULTERS and BOHLEN, 1989; MUKHOPADHYAY et al., 1991). Most of these reversals are consistent, yielding a reaction with a negative slope of approximately -4 bars $/{ }^{\circ} \mathrm{C}$ (Fig. 6). In contrast, MUKhOPADHYAY et al. (1991) located the reaction at slightly lower pressures with a positive slope of approximately 3.5 bars $/{ }^{\circ} \mathrm{C}$ (Fig. 7). The slopes and locations of other cordierite-bearing reactions can be derived from the intersection of Reaction 11 with Reactions 2 and 7 and the slopes and volume changes of the experimentally determined reactions. For instance, the reaction

$$
\text { almandine }+ \text { sillimanite }=\text { hercynite }+ \text { Fe-cordierite }
$$

$5 \mathrm{Fe}_{3} \mathrm{Al}_{2} \mathrm{Si}_{3} \mathrm{O}_{12}+2 \mathrm{Al}_{2} \mathrm{SiO}_{5}$

$$
=\mathrm{FeAl}_{2} \mathrm{O}_{4}+\mathrm{Fe}_{2} \mathrm{Al}_{4} \mathrm{Si}_{5} \mathrm{O}_{18}
$$

is derived from $1 / 3$ [Reaction $2+$ Reaction 11]. Its slope at the invariant point may be calculated as follows: $(d P / d T)_{12}$ $=\Delta S_{12} / \Delta V_{12}=1 / 3\left[\Delta S_{2}+\Delta S_{11}\right] / \Delta V_{12}=\left[(d P / d T)_{2} \Delta V_{2}\right.$ $\left.+(d P / d T)_{11} \Delta V_{11}\right] / \Delta V_{12}$. The positions of the invariant points in Figs. 6 and 7 were located by combining these calculated slopes with the experiments on the positions of the known reactions. The slopes of the reactions emanating from the invariant points were calculated as in the preceding text. The volumes of the reactions were calculated using the data in Table 6, with the exception of cordierite, whose molar volume $(237.06 \mathrm{cc} / \mathrm{mol})$ was taken from MUKHOPADHYAY et al. (1991). Two such diagrams have been derived, one locating Reaction 11 on the basis of the older experiments (Fig. 6), and one on the basis of the preliminary data of MUKHOPADHYAY et al. (1991; see Fig. 7 here). The slopes of these equilibria and the positions of the invariant points must be considered provisional. If the $\mathrm{H}_{2} \mathrm{O}$ content of $\mathrm{Fe}-$ cordierite varies dramatically along the univariant reactions involving cordierite, the actual equilibria will be curvilinear depending on the activity/composition relations for cordierite in the system $\mathrm{Fe}_{2} \mathrm{Al}_{4} \mathrm{Si}_{5} \mathrm{O}_{18}-\mathrm{H}_{2} \mathrm{O}$. The location of Reaction 10 generated in this manner in both figures is significantly different from that suggested by the experiments of HsU (1968), even corrected for the mutual solubility of hercynite and magnetite. It remains unclear whether this reflects uncertainties in the calculations or errors in the experimental data.

\section{Oxidation Equilibria of Almandine}

Redox equilibria involving almandine provide important oxygen barometers for a wide variety of rock types. The oxidation of almandine was investigated by Hsu (1968), who evaluated the upper stability limit of almandine by experiments buffered at QFM for Reaction 8. As discussed in the preceding text, to compare the calculated and the experimental position of Reaction 8 , the experiments must be corrected for the mutual miscibility of hercynite and magnetite. The activity/composition model of YAKOVLEV and VOZIANOVA (1983) may be combined with these data to correct the experiments of HSU (1968) for the spinel solutions in Reaction 8 as follows:

$$
f_{\mathrm{O}_{2}}(\text { endmember })=f_{\mathrm{O}_{2}}(\text { experimental }) /\left(a_{\mathrm{mt}}\right)^{2}\left(a_{\mathrm{hc}}\right)^{3} .
$$

This shifts Hsu's experiments on Reaction 8 by +0.20 and $+0.34 \log f_{\mathrm{O}_{2}}$ at $650^{\circ} \mathrm{C}$ and $800^{\circ} \mathrm{C}$, respectively, in good agreement with the calculated curve for the endmember reaction.

The intersection of Reactions 2 and 8 generates three reactions in $f_{\mathrm{O}_{2}}-T$ space, including the following:

$$
\begin{aligned}
& \text { almandine }+\mathrm{O}_{2}=\text { magnetite }+ \text { sillimanite }+ \text { quartz } \\
& 2 \mathrm{Fe}_{3} \mathrm{Al}_{2} \mathrm{Si}_{3} \mathrm{O}_{12}+\mathrm{O}_{2}=2 \mathrm{Fe}_{3} \mathrm{O}_{4}+2 \mathrm{Al}_{2} \mathrm{SiO}_{5}+4 \mathrm{SiO}_{2},
\end{aligned}
$$

limiting the stability of almandine at temperatures below the stability field of hercynite + quartz. Figure 8 shows these equilibria at $4 \mathrm{kbar}$. Using available experimental and thermodynamic data, FROESE (1973) calculated the $f_{\mathrm{O}_{2}}-T$ relationships for Fe-cordierite and almandine at 2 kbars and located Reaction 12 about $0.5 \log$ units more oxidizing than the present study at that pressure.

One caveat is necessary in regard to Fig. 8. Magnetite and hercynite have been treated in this diagram as separate endmember phases. Both are spinels, and there is a varying degree of solid solution between them as a function of temperature and pressure. Reactions that contain both phases will shift as the compositions of the two spinels change with temperature. These reactions will become metastable with respect to a reaction involving a single spinel phase at temperatures above the critical point of the solvus. Magnetite in equilibrium with aluminous phases other than hercynite should also contain some hercynite solid solution, and hercynite in equilibrium with iron-bearing phases may contain some magnetite component, both of which will be functions of $P, T, f_{\mathrm{O}_{2}}$. Nonetheless, metastable two-spinel reactions are useful for calculations limiting metamorphic conditions in the same way that two-garnet reactions, such as GRIPS and GAFS (BOHLEN et al., 1983b; BOHLEN and LIOTTA, 1986; ANOVITZ and ESSENE, 1987), are of great utility for thermobarometry. Thus, reactions shown in Fig. 8 include two-spinel reactions that are in reality metastable with respect to spinel solid solution(s).

The upper stability of almandine as a function of $f_{\mathrm{O}_{2}}$ has potential as an oxybarometer for many rock types. The assemblage garnet-sillimanite-magnetite-quartz is widespread in high-grade metamorphic rocks. For example, MARCOTTY ( 1983 ) described a series of iron formations at Benson Mines in the Adirondacks of New York, USA, which contain the 


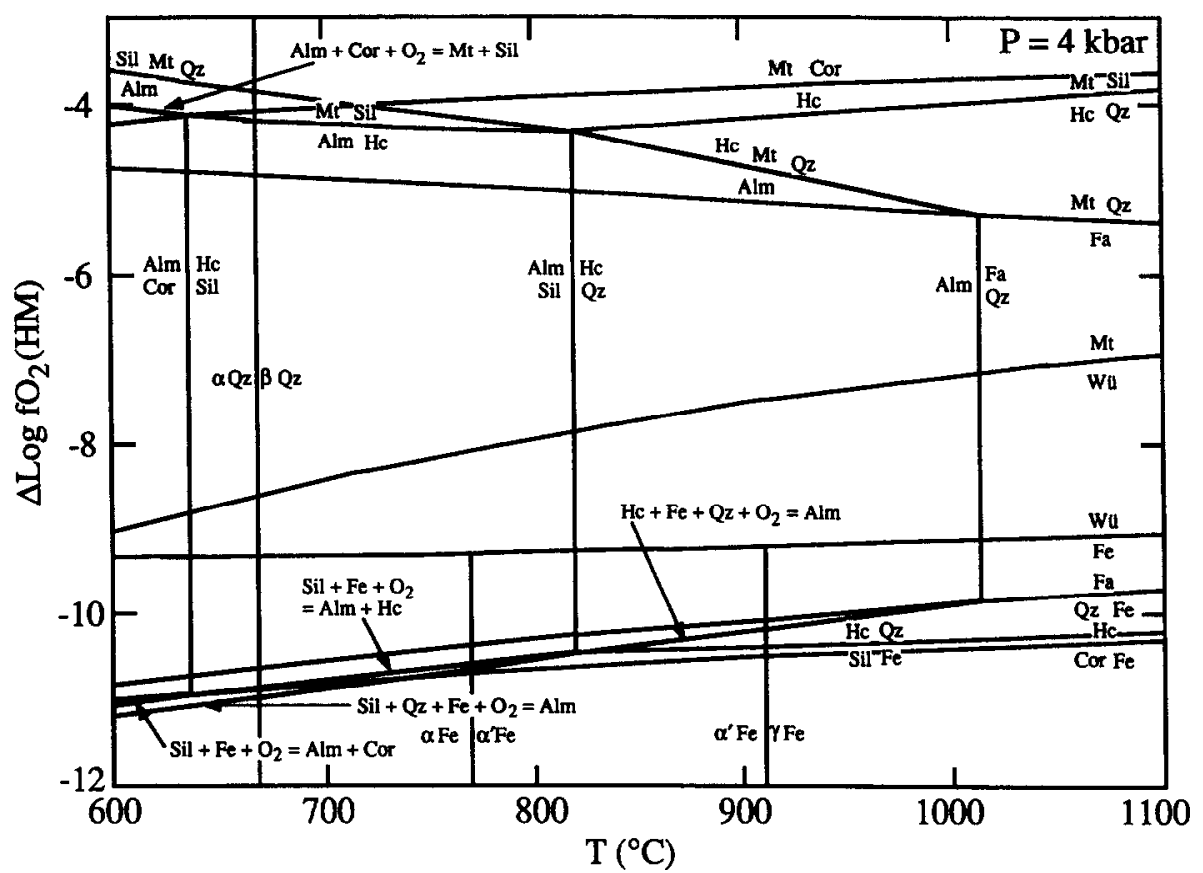

FIG. 8. Plot of $\Delta \log f_{0,}$ vs. $T$ showing the upper stability of almandine and other assemblages in the system Fe-Al$\mathrm{Si}-\mathrm{O}$ at $4 \mathrm{kbar}$ relative to the hematite-magnetite buffer. The phase equilibria are calculated with pure phases. Reactions involving $\mathrm{Mt}$ and $\mathrm{Hc}$ will shift due to the reduced mutual activities of $\mathrm{FeAl}_{2} \mathrm{O}_{4}$ and $\mathrm{Fe}_{3} \mathrm{O}_{4}$.

following assemblage: garnet-biotite-sillimanite-quartz-hercynite-magnetite \pm K-feldspar \pm ferrian ilmenite \pm högbomite \pm rutile \pm corundum (PETERSEN et al., 1989). Metamorphic conditions in this area attained $7 \mathrm{kbar}$ and $760^{\circ} \mathrm{C}$ (BOHLEN et al., 1985). MARCOTTY (1983) analyzed coexisting garnets, magnetites, hercynites, and ferrian ilmenites; representative analyses are listed in Table 8. The ilmenites, which contain exsolved hematite, were reintegrated with stepped point-beam analyses by MARCOTTY (1983). The compositions of magnetite and hercynite were reset during retrogression by external granule recrystallization to a mixture of magnetite- hercynite \pm högbomite \pm corundum \pm rutile (PETERSEN et al., 1989). However, the remainder of the assemblage may be used to estimate $f_{\mathrm{O}_{2}}$ at peak $P-T$ with the following reaction:

almandine $+\mathrm{O}_{2}=$ hematite + sillimanite + quartz

$$
\begin{array}{r}
4 \mathrm{Fe}_{3} \mathrm{Al}_{2} \mathrm{Si}_{3} \mathrm{O}_{12}+3 \mathrm{O}_{2} \\
=6 \mathrm{Fe}_{2} \mathrm{O}_{3}+4 \mathrm{Al}_{2} \mathrm{SiO}_{5}+8 \mathrm{SiO}_{2} .
\end{array}
$$

Alternatively, one could calculate the $f_{\mathrm{O}_{2}}$ required by Reaction 13 after calculating the former composition of the mag-

\begin{tabular}{|c|c|c|c|c|c|c|c|}
\hline & $\begin{array}{l}\text { 46GN } 11 \\
\text { (core) }\end{array}$ & $\underset{(\mathrm{rim})}{46 \mathrm{GN} 11}$ & 46SP5 & 46SP7 & $46 \mathrm{MT} 12$ & 46IL12 & 46INT6 \\
\hline $\mathrm{SiO}_{2}$ & 38.34 & 38.34 & - & - & - & - & - \\
\hline $\mathrm{TiO}_{2}$ & - & - & 0.34 & 0.11 & 0.12 & 48.46 & 42.67 \\
\hline $\mathrm{Al}_{2} \mathrm{O}_{3}$ & 21.35 & 21.61 & 58.78 & 59.50 & 0.17 & 0.01 & 0.00 \\
\hline $\mathrm{Fe}_{2} \mathrm{O}_{3}$ & - & - & 2.48 & 3.38 & 70.54 & 9.43 & 19.22 \\
\hline $\mathrm{FeO}$ & 30.17 & 29.76 & 31.64 & 32.58 & 32,01 & 38.37 & 37.88 \\
\hline $\mathrm{CaO}$ & 2.26 & 2.12 & - & - & - & - & - \\
\hline MnO & 5.00 & 5.34 & 3.62 & 0.65 & 0.06 & 4.84 & 0.04 \\
\hline $\mathrm{MgO}$ & 3.69 & 3.60 & 0.75 & 0.23 & 0.00 & 0.17 & 0.25 \\
\hline $\mathrm{ZnO}$ & - & - & 3.56 & 5.53 & - & - & - \\
\hline Total & 100.80 & 100.77 & 101.16 & 102.00 & 102.89 & 101.29 & 98.13 \\
\hline $\mathrm{Si}$ & 3.04 & 3.04 & - & - & - & - & - \\
\hline $\mathrm{Ti}$ & - & - & 0.007 & 0.002 & 0.003 & 0.911 & 0.816 \\
\hline AI & 2.00 & 2.02 & 1.952 & 1.932 & 0.008 & 0.000 & 0.000 \\
\hline $\mathrm{Fe}^{3+}$ & - & - & 0.044 & 0.067 & 1.986 & 0.177 & 0.368 \\
\hline $\mathrm{Fe}^{2+}$ & 2.00 & 1.97 & 0.754 & 0.753 & 1.002 & 0.802 & 0.806 \\
\hline $\mathrm{Ca}$ & 0.19 & 0.18 & - & - & - & - & - \\
\hline Mn & 0.34 & 0.36 & 0.075 & 0.013 & 0.002 & 0.103 & 0.001 \\
\hline $\mathrm{Mg}$ & 0.44 & 0.43 & 0.018 & 0.005 & 0.000 & 0.006 & 0.009 \\
\hline $\mathrm{Zn}$ & - & - & 0.149 & 0.227 & - & - & - \\
\hline
\end{tabular}

TABLE 8. Representative analyses from Benson Mine (MARCOTTY, 1983)

Note: $\mathrm{GN}=$ garnet, $\mathrm{SP}=$ aluminous spinel, $\mathrm{MT}=$ magnetite, $\mathrm{IL}=$ ilmenite, and $\mathrm{INT}=$ reintegrated hematite-ilmenite intergrowth . 
netite from the reintegrated ferrian ilmenite. Calculation of the resultant $f_{\mathrm{O}_{2}}$ yields values that lie 0.9-1.2 $\log f_{\mathrm{O}_{2}}$ units above Reaction 13 at $7 \mathrm{kbar}$ and $760^{\circ} \mathrm{C}$. While application of Reactions 13 and 14 as an oxybarometer to high-grade metamorphic rocks appears to be successful, uncertainties in activity models of spinels and garnets present difficulty for application to most rock systems that equilibrated at temperatures less than ca. $650^{\circ} \mathrm{C}$ (ESSENE, 1989).

Note added in proof: New data of HARLOV and NEwTON (1993) place the kyanite-bearing equivalent of Reaction 4 at $7.75 \pm 0.25 \mathrm{~kb}$ at $800^{\circ} \mathrm{C}$ and $5.17 \pm 0.32 \mathrm{~kb}$ at $700^{\circ} \mathrm{C}$. These data supercede those given in PETERSEN and NEWTON (1990), which are cited in the text of this paper. Our calculations yield $7.61 \mathrm{~kb}$ at $800^{\circ} \mathrm{C}$ and $4.93 \mathrm{~kb}$ at $700^{\circ} \mathrm{C}$, in agreement with the experiments. NEWTON and HARLOV (1993) have proposed that the high-temperature heat capacity and entropy should be increased to bring the experiments on GRAIL into better agreement with calculations.

Acknowledgments - This research was supported by National Science Foundation grants EAR-80-09538 to EJE and EFW, EAR-88-05083 to EJE, EAR-82-06268 to SRB, and EAR-89 05056 to LMA, and Department of Energy grant DEFG 0290 ER 14115 to LMA. We thank A. L. Montana and W. A. Dollase of the Department of Earth and Space Sciences, UCLA, for providing access and help in their laboratories for synthesis and characterization of the almandine. We also thank P. Kunde for repeated typings of early versions of the manuscript, and S. Fast and L. Koh for drafting preliminary figures. Reviews of M. A. Cosca, B. R. Frost, C. A. Geiger, E. Ghent, K. Mezger, and D. Perkins were very helpful and improved the manuscript. This is contribution No. 498 from the Thermodynamics Laboratory, Chemistry Department, and from the Mineralogical Laboratory, Department of Geological Scicnces, University of Michigan.

Editorial handling: M. S. Ghiorso

\section{REFERENCES}

Amthauer G., Annersten H., and Hafner S. S. (1976) The Mössbauer spectrum of ${ }^{57} \mathrm{Fe}$ in silicate garnets. Z. Kristallogr., Kristallgeom., Kristallphys., Kristallchem. 143, 14-55.

AMthauer C., Geiger C. A., and LotTermoser W. (1989) A Moessbauer study of synthetic almandine-grossular garnets. Terra Abstr. 1, 290.

ANOvitz L. M. and EsSENE E. J. (1987) Compatibility of geobarometers in the system $\mathrm{CaO}-\mathrm{FeO}-\mathrm{Al}_{2} \mathrm{O}_{3}-\mathrm{SiO}_{2}-\mathrm{TiO}_{2}$ (CFAST): Implications for garnet mixing models. J. Geol. 95, 633-645.

ARANOVICH L. Y. and PoDlessKII K. K. (1983) The cordieritegarnet-sillimanite-quartz equilibrium: Experiments and applications. In Kinetics and Equilibrium in Mineral Reactions; Advances in Physical Geochemistry 3 (ed. S. K. SAXENA), 172-198. SpringerVerlag.

ARMBruster T., Geiger C. A., AMTHAUER G., LOTTERMOSER W., and LAGER G. A. (1991) A single crystal X-ray and ${ }^{57}$ Fe Mössbauer spectroscopic study of synthetic pyrope-almandine garnets at 293 and $100 \mathrm{~K} . \operatorname{Eos} 72,554$.

Armbruster T., Geiger C. A., and LaGer G. A. (1992) Singlecrystal X-ray structure study of synthetic pyrope: Almandine garnets at 100 and $293 \mathrm{~K}$. Amer. Mineral. 77, 512-521.

BARROW G. (1983) On an intrusion of muscovite-biotite gneiss in the southeast highlands of Scotland and its accompanying metamorphism. Geol. Soc. London Quart. J. 49, 330-358.

BASS J. D. and WEIDNER D. J. (1984) Elasticity of single-crystal orthoferrosilite. J. Geophys. Res. 89, 4359-4372.

BERMAN R. G. ( 1988 ) Internally consistent thermodynamic data for minerals in the system $\mathrm{K}_{2} \mathrm{O}-\mathrm{Na}_{2} \mathrm{O}-\mathrm{CaO}-\mathrm{MgO}-\mathrm{FeO}-\mathrm{Fe}_{2} \mathrm{O}_{3}-\mathrm{Al}_{2} \mathrm{O}_{3}$ $\mathrm{SiO}_{2}-\mathrm{TiO}_{2}-\mathrm{H}_{2} \mathrm{O}-\mathrm{CO}_{2}$. J. Petrol. 29, 445-522.

Berman R. G. (1990) Mixing properties of Ca-Mg-Fe-Mn garnets. Amer. Mineral. 75, 328-344.

BHATTACHARYA A. (1986) Some geobarometers involving cordierite in the $\mathrm{FeO}-\mathrm{Al}_{2} \mathrm{O}_{3}-\mathrm{SiO}_{2}\left( \pm \mathrm{H}_{2} \mathrm{O}\right)$ system: Refinements, thermodynamics, calibration, and applicability in granulite facies rocks. Contrib. Mineral. Petrol. 94, 387-394.

BHATTACHARYA A. and SEN S. K. (1985) Energetics of hydration of cordierite and water barometry in cordierite granulites. Contrib. Mineral. Petrol. 89, 370-378.

Bhattacharya A., Mazumdar A. C., and Sen S. K. (1988) Fe$\mathrm{Mg}$ mixing in cordierite: Constraints from natural data and implications for cordierite-garnet geothermometry in granulites. Amer. Mineral. 73, 338-344.

BIRCH F. ( 1966) Compressibility: Elastic constants. In Handbook of Physical Constants (ed. S. P. ClARK JR.); GSA Mem. 97, 97-173.

BOHLEN S. R. and LIOTTA J. J. ( 1986) A barometer for garnet amphibolites and garnet granulites. J. Petrol. 27, 1025-1034.

BOHLEN S. R., WALl V. J., and BoETTCHER A. L. (1983a) Experimental investigations and geological applications of equilibria in the system $\mathrm{FeO}-\mathrm{TiO}_{2}-\mathrm{Al}_{2} \mathrm{O}_{3}-\mathrm{SiO}_{2}-\mathrm{H}_{2} \mathrm{O}$. Amer. Mineral. 68, 10491058.

BOHLEN S. R., WALL V. J., and BoETTCHER A. L. (1983b) Experimental investigation of model garnet granulite equilibria. Contrib. Mineral. Petrol. 83, 52-61.

Bohlen S. R., Valley J. W., and Essene E. J. ( 1985 ) Metamorphism in the Adirondacks. I. Petrology, pressure, and temperature. J. Petrol. 26, 971-992.

Bohlen S. R., DOllase W. A., and Wall V. J. ( 1986) Calibration and applications of spinel equilibria in the system $\mathrm{FeO}-\mathrm{Al}_{2} \mathrm{O}_{3}-\mathrm{SiO}_{2}$. J. Petrol. 27, 1143-1156.

BRACE W. F., SCHOLZ C. H., and LA MORI P. N. (1969) Isothermal compressibilities of kyanite, andalusite, and sillimanite from synthetic aggregates. J. Geophys. Res. 74, 2089-2098.

BROKLOFF J. E. (1964) The effect of temperature and oxidation on the reactions between iron and alumina-silica refractories. Ph.D. diss. Univ. Michigan.

Chatillon-COlinet C., Kleppa O. J., Newton R. C., and Perkins D. III (1983) Enthalpy of formation of $\mathrm{Fe}_{3} \mathrm{Al}_{2} \mathrm{Si}_{3} \mathrm{O}_{12}$ (almandine) by high-temperature alkali borate solution calorimetry. Geochim. Cosmochim. Acta 47, 439-444.

CHATTERIEF N. ( 1987 ) Fvaluation of thermochemical data on Fe$\mathrm{Mg}$ olivine, orthopyroxene, spinel, and $\mathrm{Ca}-\mathrm{Fe}-\mathrm{Mg}-\mathrm{Al}$ garnet. Geochim. Cosmochim. Acta 51, 2515-2525.

COHEN L. H. and KLEMENT W. JR. (1967) High-low quartz inversion determination to 35 kilobars. J. Geophys. Res. 72, 4245-4251.

CURRIE K. L. (1971) The reaction 3 cordierite $=2$ garnet +4 sillimanite +5 quart $<$ as a geological thermometer in the Opinicon Lake Region, Ontario. Contrib. Mineral. Petrol. 33, 215-226.

ESSENE E. J. ( 1989) The current status of thermobarometry in metamorphic rocks. In Evolution of Metamorphic Belts (ed. J. S. DALY, R. ClifF, and B. W. D. YARDLEY); GSA Spec. Pub. 43, 1-44.

FED'KIN V. V. (1970) Calculation of mineral equilibria in the system $\mathrm{FeO}-\mathrm{Al}_{2} \mathrm{O}_{3}-\mathrm{SiO}_{2}-\mathrm{O}_{2}$. Geol. Geofiz. 12, 22-38.

FROESE E. (1973) The oxidation of almandine and cordierite. $\mathrm{Ca}$ nadian Mineral. 11, 991-1002.

Geiger C. A., LotTermoser W., and Amthauer G. (1990) A temperature-dependent ${ }^{57} \mathrm{Fe}$ Moessbauer study of synthetic almandine-grossular and almandine-pyrope garnets: A comparison. 3rd Intl. Conf. on Exp. Minerol. Petrol and Geochem., 11.

HAAS J. L. and FiSHER J. R. (1976) Simultaneous evaluation and correlation of thermodynamic data. Amer. J. Sci. 276, 525-545.

HaRlov D. E. and NEWTON R. C. (1992) Experimental determination of the reaction 2 magnetite +2 kyanite +4 quartz $=2$ almandine $+\mathrm{O}_{2}$ at high pressures on the magnetite-hematite buffer. Amer. Mineral. 77, 558-564.

HARLOV D. E. and NEWTON R. C. (1993) Reversal of the metastable kyanite + corundum + quartz and andalusite + corundum + quartz equilibria and the enthalpy of formation of kyanite and andalusite, Amer. Mineral. 78, 594-600.

Haselton H. T. and Westrum E. F. JR. ( 1980) Low-temperature heat capacities of synthetic pyrope, grossular, and pyrope 60 grossular $_{40}$. Geochim. Cosmochim. Acta 44, 701-709.

Helgeson H. C., Delany J. M., Nesbitt H. W., and Bird D. K. (1978) Summary and critique of the thermodynamic properties of rock-forming mincrals. Amer J. Sci. 278A.

HEMINGWAY B. S. ( 1987) Quartz: Heat capacities from 340 to 1000 
$\mathrm{K}$ and revised values for the thermodynamic properties. Amer. Mineral. 72, 273-279.

HemingWay B. S., KRUPKA K. M., and ROBIE R. A. (1981) Heat capacities of the alkali feldspars between $350-1000 \mathrm{~K}$ from differential scanning calorimetry; the thermodynamic functions of alkali feldspars from 298.15 to $1400 \mathrm{~K}$ and the reaction quartz + jadeite $=$ analbite. Amer. Mineral. 66, 1205-1215.

Hemingway B. S., Robie R. A., Evans H. T., JR., and Kerrick D. M. (1991) Heat capacities and entropies of sillimanite, fibrolite, andalusite, kyanite, and quartz and the $\mathrm{Al}_{2} \mathrm{SiO}_{5}$ phase diagram. Amer. Mineral. 76, 1597-1613.

HENSEN B. J. ( 1971) Theoretical phase relations involving cordierite and garnet in the system $\mathrm{MgO}-\mathrm{FeO}-\mathrm{Al}_{2} \mathrm{O}_{3}-\mathrm{SiO}_{2}$. Contrib. Mineral. Petrol. 33, 191-214.

HENSEN B. J. (1972) Cordierite-garnet equilibrium as a function of pressure, temperature, and iron-magnesium ratio. Carnegie Inst. Wash. Yearb. 71, 418-421.

HENSEN B. J. and GREEN D. H. (1973) Experimental study of the stability of cordierite and garnet in pelitic compositions at high pressures and temperatures. III. Synthesis of experimental data and geological applications. Contrib. Mineral. Petrol. 38, 151-166.

HOLDAWAY M. J. and LEE S. M. ( 1977) Mg-Fe cordierite stability in high-grade pelitic rocks based on experimental, theoretical, and natural observations. Contrib. Mineral. Petrol. 63, 175-198.

HollaND T. J. B. and Powell R. (1990) An enlarged and updated internally consistent thermodynamic data set with uncertainties and correlations: The system $\mathrm{K}_{2} \mathrm{O}-\mathrm{Na}_{2} \mathrm{O}-\mathrm{CaO}-\mathrm{MgO}-\mathrm{MnO}-\mathrm{FeO}$ $\mathrm{Fe}_{2} \mathrm{O}_{3}-\mathrm{Al}_{2} \mathrm{O}_{3}-\mathrm{TiO}_{2}-\mathrm{SiO}_{2}-\mathrm{C}_{-} \mathrm{H}_{2}-\mathrm{O}_{2}$. J. Metam. Geol. 8, 89-124.

Hsu L. C. (1968) Selected phase relationships in the system Al-MnFe-Si-O-H: A model for garnet equilibria. J. Petrol. 9, 40-83.

HUTCHEON I., FROESE E., and GORDON T. M. (1974) The assemblage quartz-sillimanite-garnet-cordierite as an indicator of metamorphic conditions in the Daly Bay Complex, NWT. Contrib. Mineral. Petrol. 44, 29-34.

Jo:iannes W., Bell M., Mao H. K., Boettcher A. L., Chipman D. W., HaYS J. F., Newton R. C., and Seifert F. (1971) An interlaboratory comparison of piston-cylinder pressure calibration using the albite breakdown reaction. Contrib. Mineral. Petrol. 32, 24-78.

JUSTICE B. H. ( 1969) Thermal data fitting with orthogonal functions and combined table generation. US Atomic Energy Commission Rept. No. C00-1149-143.

KARPOV I. K., DOROGEKOPETS P. I., and LASHKEVICH V. V. (1977) Optimal thermodynamic properties of rock forming minerals. In Geochemistry of Endogenic Processes (ed. L. V. TAUSON), pp. 196-202. Nauka.

KaWASAKI T. and Matsui Y. (1977) Partitioning of $\mathrm{Fe}^{2+}$ and $\mathrm{Mg}$ between olivine and garnet. Earth Planet. Sci. Lett. 37, 159-166.

KIEFFER S. W. (1980) Thermodynamics and lattice vibrations of minerals 4. Applications to chain and sheet silicates and orthosilicates. Rev. Geophys. Space Phys. 18, 862-886.

KING E. G. ( 1955 ) Hcat capacities at low temperature and entropies of five spinel minerals. J. Phys. Chem. 60, 410-412.

KitTel C. (1986) Introduction to Solid State Physics, 6th ed. John Wiley.

Kolesnik Y. N., Nogtova V. V., ARKhipenko D. K., OREKov B. A., and PAUKOV I. Y. (1979) Thermodynamics of pyrope-grossular solid solutions and specific heat of grossular at $13-1300 \mathrm{~K}$. Geochem. Intl. 16:3, 57-64.

LEE S. M. and HoldawAY M. J. (1977) Significance of Fe-Mgcordierite stability relations on temperature, pressure, and water pressure in cordierite granulites. In The Earth's Crust (ed. J. G. HEACOCK); $A G U$ Monogr. Ser. 20, 559-588.

LIEBERMAN R. C. and RINGwoOd A. E. (1976) Elastic properties of anorthite and the nature of the lunar crust. Earth Planet. Sci. Lett. 31, 69-74.

LONKER S. W. (1981) The P-T-X relations of the cordierite-garnetquartz equilibrium. Amer. J. Sci. 281, $1056-1090$.

MARCOTTY L.-A. (1983) The petrology of the magnetite paragneisses at Benson Mines, Adirondacks, New York. M.S. thesis, Univ. Michigan.

MARTIGNOLE J. and SISI J.-C. ( 1981 ) Cordierite-garnet- $\mathrm{H}_{2} \mathrm{O}$ equi- librium: A geological thermometer, barometer, and water fugacity indicator. Contrib. Mineral. Petrol. 77, 38-46.

MCLEAN A. and WARD R. G. (1966) Thermodynamics of hercynite formation. J. Iron Steel Inst. 204, 8-11.

METZ G. W., ANOVITZ L. M., ESSENE E. J., BOHLEN S. R., WESTRUM E. F., JR., and WALL V. J. (1983) The heat-capacity and phase equilibria of almandine. Eos 64, 347-347.

MOECHER D. P., ESSENE E. J., and ANOVITZ L. M. ( 1988) Calculation of clinopyroxene-garnet-plagioclase-quartz geobarometers and application to high-grade metamorphic rocks. Contrib. Mineral. Petrol. 100, 92-106.

MUKhopadhyay B., Holdaway M. J., and DyaR M. D. (1991) New experimental determination of the reaction: Fe-cordierite $=$ almandine + sillimanite + quartz under hydrous conditions. GSA Abstr. Prog. 23, 391-392.

MURAD E. and WAGNER F. E. (1987) The Mössbauer spectrum of almandine. Phys. Chem. Minerals 14, 264-269.

NEWTON R. C. and HARLOV D. E. (1993b) Standard thermodynamic properties of almandine. Canadian Mineral. (in press).

NEWTON R. C. and WoOD B. J. (1979) Thermodynamics of water in cordierite and some petrologic consequences of cordierite as a hydrous phase. Contrib. Mineral. Petrol. 68, 391-405.

OLINGER B. and HALLECK P. M. (1976) The compression of alpha quartz. J. Geophys. Res. 81, 5711-5714.

O'NEILL H. ST. C. (1987) Quartz-fayalite-iron and quartz-fayalitemagnetite equilibria and the free energy of formation of fayalite $\left(\mathrm{Fe}_{2} \mathrm{SiO}_{4}\right)$ and magnetite $\left(\mathrm{Fe}_{3} \mathrm{O}_{4}\right)$. Amer. Mineral. 72, 67-72.

O'NEILl H. ST. C. and NAVROTSKY A. (1983) Simple spinels: Crystallographic parameters, cation radii, lattice energies, and cation distribution. Amer. Mineral. 68, 181-194.

PERKINS D., ESSENE E. J., and WALL V. J. (1987) Computer program for calculation of mixed volatile equilibria. Amer. Mineral. 72 , 446-447.

PETERSEN D. E. and NeWTON, R. C. (1990) Free energy and enthalpy of formation of kyanite. GSA Abstr. Prog. 22, 342.

Petersen E. U., Essene E. J., Peacor D. R., and Marcotty L.-A. (1989) The occurence of högbomite in high-grade metamorphic rocks. Contrib. Mineral. Petrol. 101, 350-360.

Pillay T. C., D'ENTREMONT J., and ChipMan J. (1960) Stability of hercynite at high temperatures. J. Amer. Ceramic Soc. 43, 583585.

PRANDEL W. (1971) Magnetic structure and atomic parameters of almandite $\mathrm{Al}_{2} \mathrm{Fe}_{3}\left(\mathrm{SiO}_{4}\right)_{3}$. Z. Kristallogr., Kristallgeom., Kristallphys., Kristallchem. 134, 334-343.

Rezukina T. N., Levitski V. A., and Ozhegov P. (1963) Thermodynamic properties of iron aluminate. Russian J. Phys. Chem. 37, 358--359.

RICHARDSON S. W. (1968) Staurolite stability in a part of the system Fe-Al-Si-O-H. J. Petrol. 9, 467-488.

RoBIE R. A. (1987) Calorimetry. In Hydrothermal Experimental Techniques (ed. G. C. ULMER and H. L. BARNES), pp. 389-422. Wiley-Interscience.

ROBIE R. A. and HEMINGWAY B. S. (1984) Entropies of kyanite, andalusite, and sillimanite: Additional constraints on the pressure and temperature of the $\mathrm{Al}_{2} \mathrm{SiO}_{5}$ triple point. Amer. Mineral. 69, 298-306.

Robie R. A., Bethke P. M., and Beardsley K. M. ( 1967) Selected $X$-ray crystallographic data, molar volumes, and densities of minerals and related substances. US GS Bull. 1248.

Robie R. A., Hemingway B. S., and FisHer J. R. (1978) Thermodynamic properties of minerals and related substances at 1 bar ( $10^{5}$ Pascals) pressure and at higher temperatures. US Geol. Surv. Bull. 1452. (reprinted with revisions, 1979).

Robie R. A., FinCH C. B., and Hemingway B. S. (1982) Heatcapacity and entropy of fayalite $\left(\mathrm{Fe}_{2} \mathrm{SiO}_{4}\right)$ between 5.1 and 383 $\mathrm{K}$ : Comparison of calorimetric and equilibrium values for the QFM buffer reaction. Amer. Mineral. 67, 463-469.

RoBINSON G. R., JR., and HAAS J. L., JR. (1983) Heat capacity, relative enthalpy, and calorimetric entropy of silicate minerals: An empirical method of prediction. Amer. Mineral. 68, 541-553.

Robinson G. R., JR., HAAS J. L., JR., SCHAFER C. M., and HASELTON H. T., JR. (1983) Thermochemical and thermophysical properties of selected phases in $\mathrm{MgO}-\mathrm{SiO}_{2}-\mathrm{H}_{2} \mathrm{O}-\mathrm{CO}_{2}, \mathrm{CaO}-\mathrm{Al}_{2} \mathrm{O}_{3}$ - 
$\mathrm{SiO}_{2}-\mathrm{H}_{2} \mathrm{O}-\mathrm{CO}_{2}$, and $\mathrm{Fe}-\mathrm{FeO}-\mathrm{Fe}_{2} \mathrm{O}_{3}-\mathrm{SiO}_{2}$ chemical systems with special emphasis on the properties of basalts and their mineral components. USGS Open-File Rept. 83-79.

ROTH W. L. (1964) Magnetic properties of normal spinel with only A-A interactions. J. Physics 25, 507-515.

RUBY S. L. (1973) Why misfit when you already have $\mathrm{X}^{2}$ ? In Mössbauer Effect Methodology (ed. I. J. GRUVERMAN and C. W. SEIDEL) Vol. 8, pp. 263-276.

SACK R. O. (1983) Spinels as petrogenetic indicators: Activity-composition relations at low pressures. Contrib. Mineral. Petrol. 79, 164-186.

SHULTERS J. and BOHLEN S. R. (1989) The stability of hercynitegahnite spinels in corundum- or quartz-bearing assemblages. $J$. Petrol. 30, 1017-1032.

SKINNER B. J. ( 1966) Thermal Expansion. In Handbook of Physical Constants (ed. S. P. CLARK JR.); GSA Mem. 97, 75-96.

Slaughter J., Wall V. J., and KeRRICK D. M. (1976) APL computer programs for thermodynamic calculations of equilibria in P-T-X $\left(\mathrm{CO}_{2}\right)$ space. Contrib. Mineral. Petrol. 54, 157-171.

ThOMPSON A. B. (1976a) Mineral reactions in pelitic rocks. I. Prediction of P-T-X (Fe-Mg) phase relations. Amer. J. Sci. 276, 401424.

ThOMPSON A. B. (1976b) Mineral reactions in pelitic rocks. II. Calculations of some P-T-X (Fe-Mg) phase relations. Amer. J. Sci. 276, 425-454.

TOPOR L., KLEPPA O. J., NEWTON R. C., and KERRICK D. M. (1989) Molten salt calorimetry of $\mathrm{Al}_{2} \mathrm{SiO}_{3}$ polymorphs at $1000 \mathrm{~K}$. EOS 70, 493.

Turnock A. L. and Eugster H. P. (1962) Fe-Al oxides: Phase relationships below $1000^{\circ} \mathrm{C}$. J. Petrol. 3, 533-565.

ULBRICH H. H. and WALDBAUM D. R. (1976) Structural and other contributions to the third law entropies of silicates. Geochim. Cosmochim. Acta 40, 1-24.
Vaidya S. N., Bailey S., Pasternack T., and Kennedy G. C. ( 1973 ) Compressibility of fifteen minerals to 45 kilobars. J. Geophys. Res. 78, 6893-6898.

WANG H. and SIMMONS G. (1972) Elasticity of some mantle crystal structures: I. Pleonaste and hercynite spinel. J. Geophys. Res. 77, 4379-4392.

WECHLER B. A. and PREWITT C. T. (1984) Crystal structure of ilmenite $\left(\mathrm{FeTiO}_{3}\right)$ at high temperature and high pressure. Amer. Mineral. 69, 176-185.

WEISBROD A. (1973) Refinements of the equilibrium conditions of the reaction Fe-cordierite $=$ garnet + sillimanite + quartz $\left( \pm \mathrm{H}_{2} \mathrm{O}\right)$. Carnegie Inst. Wash. Yearb, 72, 515-522.

WESTRUM E. F., JR. ( 1984) Computcrized adiabatic thermophysical calorimetry. In Thermochemistry and Its Applications to Chemical and Biochemical Systems (ed. M. A. V. RIBERO DA SILVA), pp. 745-767. Reidel.

Westrum E. F., JR., EsSENe E. J., and PERKINS D. III (1979) Thermophysical properties of the garnet grossular: $\mathrm{Ca}_{3} \mathrm{Al}_{2} \mathrm{Si}_{3} \mathrm{O}_{12} . J$ Chem. Therm. 11, 57-66.

WILBURN D. R., BASSETT W., and SATO Y. (1978) X-ray diffraction compression studies of hematite under hydrostatic isothermal conditions. J. Geophys. Res. 86, 3509-3512.

WINTER J. K. and GHOSE S. (1979) Thermal expansion and hightemperature crystal chemistry of $\mathrm{Al}_{2} \mathrm{SiO}_{5}$ polymorphs. Amer. Mineral. 64, 573-586.

WOODLAND A. B. and Wood B. J. (1989) Electrochemical measurement of the free energy of almandine $\left(\mathrm{Fe}_{3} \mathrm{Al}_{2} \mathrm{Si}_{3} \mathrm{O}_{12}\right)$ garnet. Geochim. Cosmochim. Acta 53, 2277-2282.

YaKovLEV B. G. and Vozianova O. V. (1983) The thermodynamic parameters of almandine. Geochem. Intl. 20, 50-61.

ZEN E-A. (1973) Thermochemical parameters of minerals from oxygen-buffered hydrothermal equilibrium data: Method and application to annite and almandine. Contrib. Mineral. Petrol. 39, 6580 . 